\title{
MASTER
}

\section{CONSTRUCTION OF CALIBRATION PADS FACILITY WALKER FIELD, GRAND JUNCTION, COLORADO}

\section{Bendix Field Engineering Corporation Grand Junction Operations Grand Junction, Colorado 81501}

August 1978

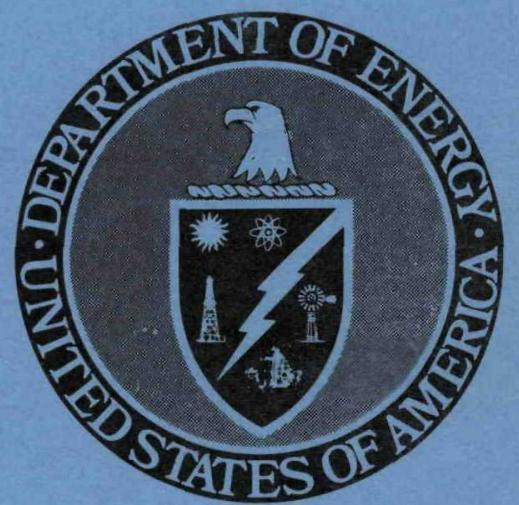

ISSUED BY THE U.S. DEPARTMENT OF ENERGY GRAND JUNCTION OFFICE UNDER CONTRACT NO. EY-76-C-13-1664 
This report was prepared as an account of work sponsored by the United States Government. Neither the United States nor the United States Department of Energy, nor any of their employees, nor any of their contractors, subcontractors, or their employees, makes any warranty, express or implied, or assumes any legal liability or responsibility for the accuracy, completeness or usefulness of any information, apparatus, product or process disclosed, or represents that its use would not infringe privately owned rights. 


\section{DISCLAIMER}

This report was prepared as an account of work sponsored by an agency of the United States Government. Neither the United States Government nor any agency Thereof, nor any of their employees, makes any warranty, express or implied, or assumes any legal liability or responsibility for the accuracy, completeness, or usefulness of any information, apparatus, product, or process disclosed, or represents that its use would not infringe privately owned rights. Reference herein to any specific commercial product, process, or service by trade name, trademark, manufacturer, or otherwise does not necessarily constitute or imply its endorsement, recommendation, or favoring by the United States Government or any agency thereof. The views and opinions of authors expressed herein do not necessarily state or reflect those of the United States Government or any agency thereof. 


\section{DISCLAIMER}

Portions of this document may be illegible in electronic image products. Images are produced from the best available original document. 
CONSTRUCTION OF CALIBRATION PADS FACILITY WALKER FIELD, GRAND JUNCTION, COLORADO

Dan L. Ward

BENDIX FIELD ENGINEERING CORPORATION Grand Junction Operations Grand Junction, Colorado 81501

Thus report was prepased as an acceunt of wark sponsored by the Unted States Government Nerther the United States nor the I nated States Department of Tnergy nor any of their enployees nar any of their contrathers subcontrattons or th etr employes rales any warranty, express or molied or assames ans bon labuiny or respesasibulaty tor the anurac completeness or usefulness of anv information apparatus preduct on process alls losed an represents that ts we would or uffenge proately owned nghts

\footnotetext{
August 1978

\section{ISSUED BY THE U.S. DEPARTMENT OF ENERGY GRAND JUNCTION OFFICE
UNDER CONTRACT NO. EY-76-C-13-1664

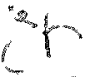


Section

Page

Introduction

Spectrometer Characteristics and Calibration

Construction

Radioelement Sources

Design and Function

Aggregate Blending and Storage

Pouring and Finishing the Pads

Pad Concentrations

Calibration Procedures

Operational Procedures

Environmental Considerations

Notice to Corporate or Individual Users of this Facility

\section{LIST OF ILLUSTRATIONS}

1. Index Map of the United States Showing Location of Grand Junction, Colorado and DOE/GJO District offices

2. Aerial Photograph of Walker Field Airport, Grand Junction, Colorado

3. DOE Calibration Pads, Walker Field Airport, Grand Junction, Colorado

4. Airport Pad Cross Section 8

5. Environmental Radiometric Survey Map 15

\section{TABLES}

1. Chemical Analyses of Aggregate Used in Pad Construction

2. Airport Pad Concentrations and Densities

\section{APPENDICES}

A. Mineralogic and Petrologic Analysis A-1

B. Material Weights and Blending Procedures B-1

C. Photographic Review of Construction Activities C-1 


\section{INTRODUCTION}

The U. S. Department of Energy (DOE) is engaged in a program to delineate areas in which the geological environment and sequence of sediments suggest the presence of a potentially favorable host rock for the accumulation of uranium. The development of technology, including equipment and techniques for the exploration and assay of uranium ores, is an important part of this program. Airborne gamma-ray spectrometer systems provide a major source of information for the uranium resource assessment, and calibration of these instruments is essential to reliable aerial survey data interpretation and correlation.

A gamma-ray spectrometer calibration facility was completed at Walker Field Airport, Grand Junction, Colorado in November 1976 by Bendix Field Engineering Corporation (BFEC) for DOE. Grand Junction was selected as the site for the facility because of its central location in the United States (Figure 1), its proximity to areas of active uranium exploration, and the availability of BFEC personnel at the DOE-Grand Junction office to provide maintenance and operational supervision as required. The location of the facility is shown in Figure 2, an aerial photograph of Walker Field. Although designed specifically for aircraft, the usefulness of the facility also extends to the calibration of vehicular mounted or hand portable spectrometers. The calibration facility at Grand Junction provides the uranium industry with a single set of reference standards and a facility at which the information necessary for the interpretation of aerial radiometric survey data can be determined.

The following report describes spectrometers and their calibration, the construction of the facility at Walker field, the radioelement concentrations, procedures for using the facilities, and environmental considerations.

\section{SPECTROMETER CHARACTERISTICS AND CALIBRATION}

The primary radioelements for which concentrations are determined by gamma-ray spectrometry in the investigation of the natural radiation environment are potassium, uranium, and thorium; and their concentrations are determined by measuring the activity of the gamma-ray emissions at specific energy levels characteristic of each element. Potassium is measured directly using the 1.46 Mev gamma-ray energy emitted by potassium 40. Uranium and thorium are measured indirectly from radioelements within their respective decay schemes, uranium by observing the radiation of its daughter product bismuth 214 (1.76 Mev), and thorium by the gamma rays of thallium 208 (2.62 Mev). 


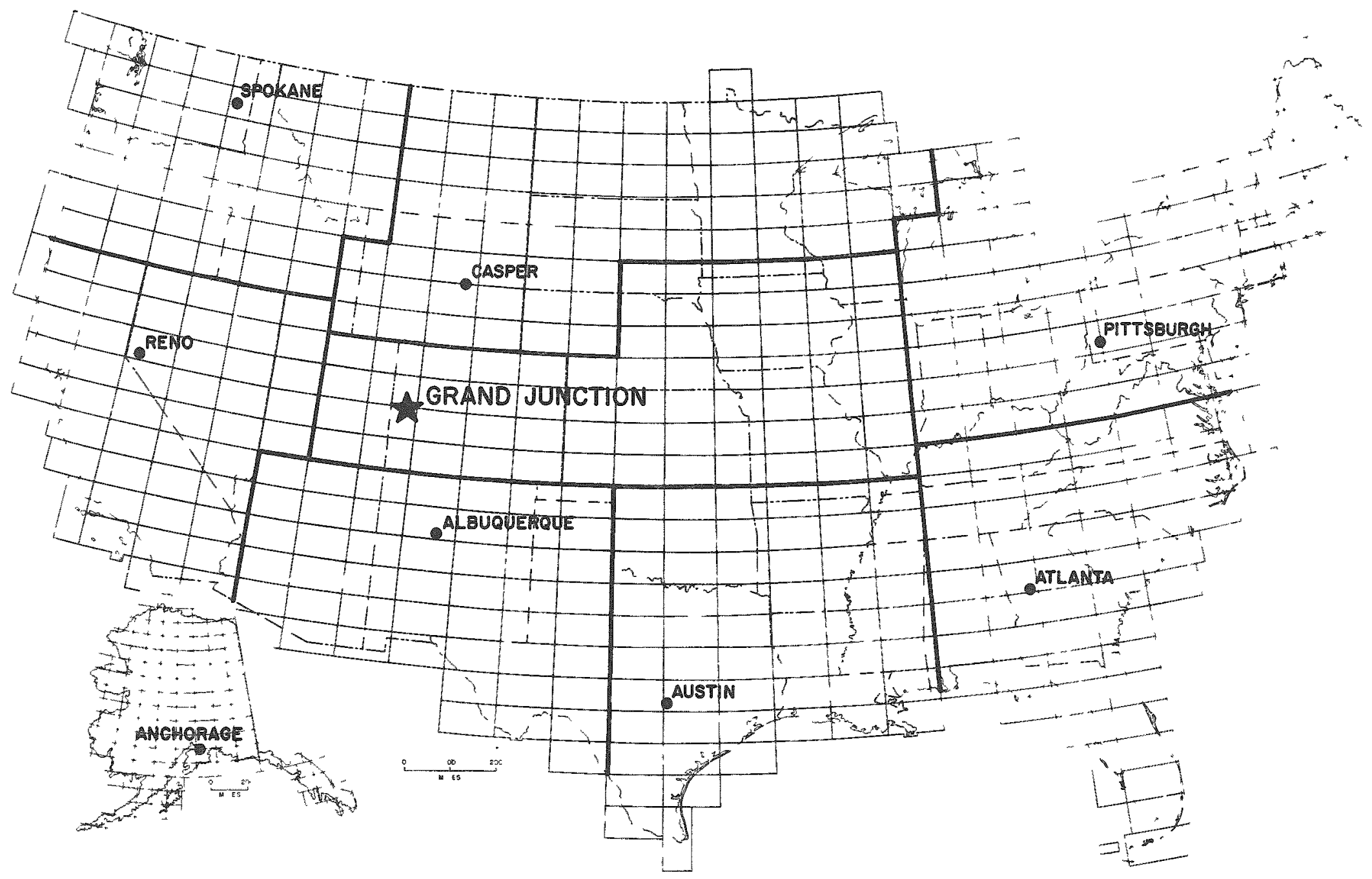

FIGURE 1

INDEX MAP OF THE UNITED STATES SHOWING LOCATION OF GRAND JUNCTION, COLORADO AND DOE-GJO DISTRICT OFFICES 


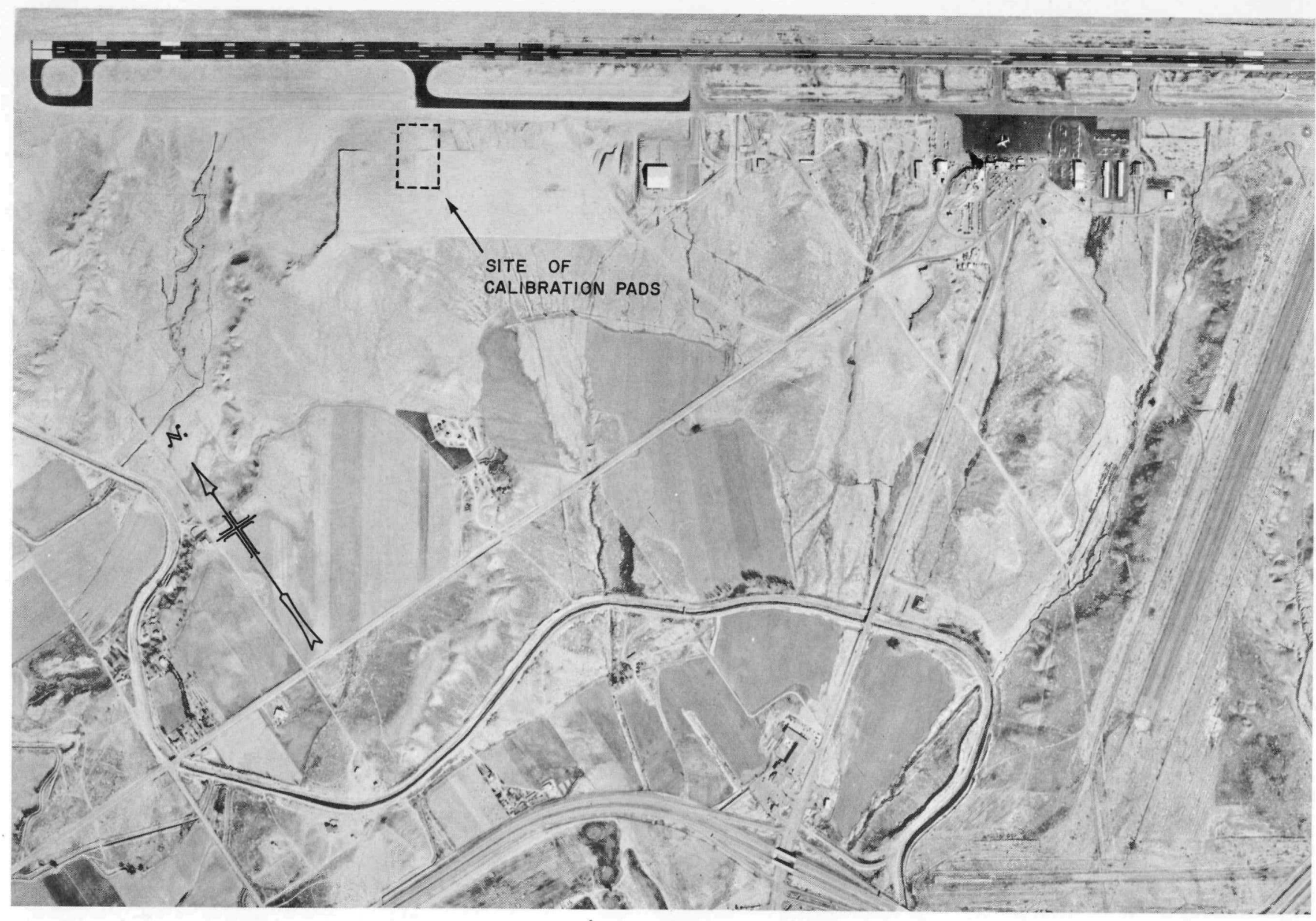

FIGURE 2

AERIAL PHOTOGRAPH OF WALKER FIELD AIRPORT, GRAND JUNCTION, COLORADO 
Spectrometers utilize energy windows to distinguish the gamma-ray activity for specific radioelements. Energy degradation primarily due to Compton scattering, however, results in some energy from thorium occurring in the uranium and potassium windows, and some energy from uranium occurring in the potassium window. Removal of this Compton scattering effect is accomplished mathematically by a stripping procedure that removes the contribution of high energy gamma rays occurring in a lower energy window. The input data for calculation of the stripping factors is the number of gamma-ray occurring for a given period within specific energy windows when a detector is exposed to known concentrations of radioactive source material as is present in the calibration pads. To improve the accuracy in the determination of spectral sensitivities of the radioelements from aerial survey data, the stripping ratio determined on the calibration pads for uranium/thorium (U/Th) should be corrected for flight altitude in accordance with the linear absorption coefficient for air (Grasty, 1975). The mathematical determination of stripping ratios and sensitivities utilizing aerial radiometric data are considered in a number of technical papers and will not be addressed in this discussion.

Calibration factors should be determined at frequent intervals to establish a satisfactory level of reliability of performance and accuracy. It is very important that the instruments be capable of consistent data output, and no significant change in calibration factors from one time to another should exist if the equipment system is functioning properly and has not been modified. Without this consistency or repeatability, interpretation is virtually impossible.

The response characteristics of the detector and counting system must be determined prior to the survey and must remain consistent throughout the survey if the collected data are to be accurately interpreted or correlated with other geological information. Calibration during surveys of long duration provide evidence of the response consistency of the equipment. In the event of an equipment failure, whether it is a total failure or perhaps a slight drift that could bias the information, calibration factors determined near the time of the equipment failure could prevent the loss of substantial flight time and survey data. Surveys interrupted for long periods by equipment failure, weather conditions, etc. can be accurately correlated with new data when the survey is continued by checking the calibration factors on the pads. Adjoining surveys over the same area conducted by different instrument systems can be correlated with good results if accurate calibration factors are available.

Detailed requirements for use of these pads by DOE/BFEC contractors are given in specification document "General Procedure and Documentation for Normalization and Calibration of Airborne Gamma-Ray Systems" BFEC 1250-A and in open file report "procedures and Regulations for Airport Calibration Pads Walker Field, Grand Junction, Colorado" No. GJBX-38(78). 


\section{Radioelement Sources}

Careful consideration was given to selection of the radioelement source material so that the observed gamma-ray spectrum from the pads would closely resemble the spectrum of the natural radiation environment. Identifiable contributions for potassium, uranium, and thorium at several concentrations each were required for optimum calibration reliability. Potassium feldspar in a pink, orthoclase granite provides the potassium $\left({ }^{40} \mathrm{~K}\right)$ constituent. The uranium constituent $(214 \mathrm{Bi})$ is a primary pitchblende ore that is in close secular equilibrium with its daughter products. The thorium constituent $\left({ }^{208} \mathrm{Th}\right)$ occurs in a monazite sand.

Masonry sand was selected as the matrix material because of its high percentage of angular, silica sand for strength and its size consistency ( 10 mesh). The radioactive ores to be blended with the sand matrix were also crushed to 10 mesh to achieve better homogeneity within the total blended aggregate.

Appendix A contains detailed mineralogic and petrologic descriptions, sieve analyses of the crushed ores, and heavy mineral analyses of the sand and ores used in the pad construction. Table 1 below lists the data obtained from chemical analyses of the potassium, uranium, and thorium ores, the matrix sand, and the cement used in construction of the pads.

Table 1

Chemical Analyses of Aggregate Used in Pad Construction $\underline{\text { AGGREGATE }} \underline{K} \quad \underline{U} \quad \underline{T h}$

$\begin{array}{lllc}\text { Feldspar ore } & 8.54 \% & 3 \mathrm{ppm} & 2 \mathrm{ppm} \\ \text { Uranium Ore } & 4.21 \% & 2.58 \% & 36.0 \mathrm{ppm} \\ \text { Thorium Ore } & 0.06 \% & 0.37 \% & 3.95 \% \\ \text { Sand } & 1.99 \% & 3 \mathrm{ppm} & 8 \mathrm{ppm} \\ \text { Cement } & 0.49 \% & 3 \mathrm{ppm} & 5 \mathrm{ppm}\end{array}$

\section{Design and Function}

Figure 3 is a diagram of the calibration facility located in a 4-acre tract west of runway $11 / 29$. The facility consists of five concrete pads ( $30 \mathrm{ft} \times 40 \mathrm{ft} \times 1.5 \mathrm{ft}$ ) interconnected by an asphalt taxiway. Pad 1 is the zero reference that consists of concrete containing no added radioelements although the sand and cement have some minor amounts approximating the natural radioactivity of the 


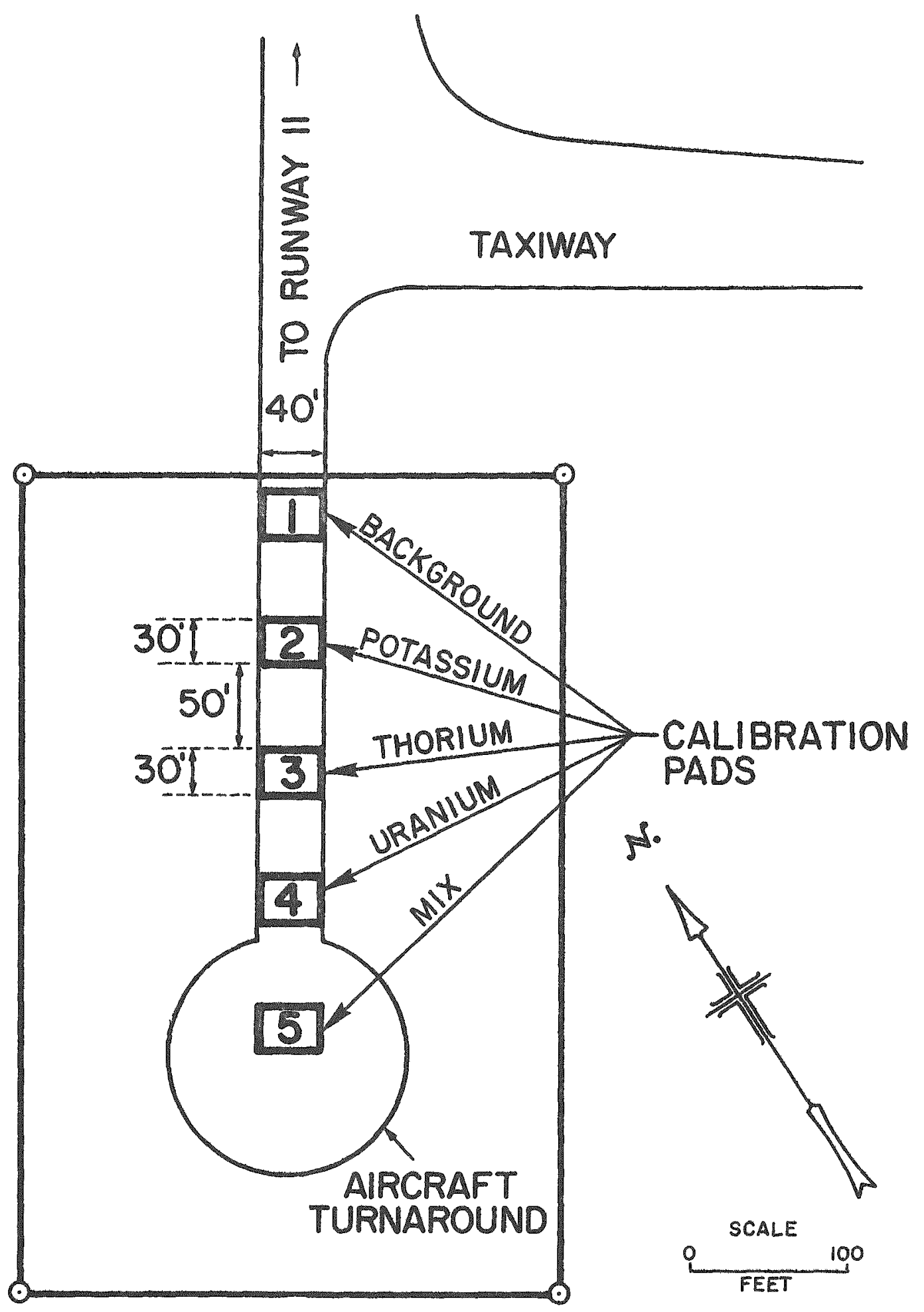

FIGURE 3

DOE CALIBRATION PADS

WALKER FIELD AIRPORT, GRAND JUNCTION, COLORADO 
soil in the area. Pads 2, 3, and 4 contain measured concentrations of potassium, uranium, and thorium, and one of these elements occurs in a slightly higher concentration in each of the pads. Pad 2 is the potassium pad, pad 3 the thorium pad, and pad 4 contains a relatively higher concentration of uranium. From the data obtained from pads one through four, stripping ratios and radioelement sensitivities can be determined. Pad 5 contains concentrations characteristic of a uranium ore body, and the data collected on this pad is used to confirm the accuracy of the calibration information collected on the other four pads. An asphalt skirt around pad 5 allows planes to turn around and leave the facility under their own power.

Figure 4 is a cross-section of a calibration pad. The top is flat so that the angle between the detector and the pad surface is constant for each distance measured from the center of the pad. Joints ( $1 / 4 \mathrm{in}$. wide $\times 4 \mathrm{in}$. deep) are cut across the total surface length of the pads to control cracking due to contraction or subsequent movement of the concrete blocks. The concrete is on top of a 6 inch asphalt base to provide stability for the pads because the soil is of poor quality for foundations. The sides of the pads are coated with a black asphaltic sealer to prevent water encroachment from the soil.

\section{Aggregrate Blending and Storage}

Because it was necessary to obtain desired levels of radioactivity for three separate elements (potassium, uranium, and thorium) in each pad and also to obtain homogeneity within the pad for all radioelements, careful weight measurement of all constituents was required. Particular attention was paid to blending procedures (Appendix $B$ ). By chemical assay (Table 1), the concentration of each radioelement (percent potassium, ppm uranium and thorium) in units based on dry weight was determined for the radioactive ores, masonry sand, and cement. The specific gravity of these materials was also determined, and the total weight for each pad calculated for a total of 67 cubic yards, the pad volume. Each constituent part of the aggregate mixture was weighed and stored in 55-gallon drums.

The moisture content of the sand and radioactive ores was determined by measuring the percent loss of weight from a sample of the material before and after being heated to a temperature of $110^{\circ} \mathrm{C}$. Because the analytical concentrations were measured in percent of dry weight and the bulk material to be blended contained moisture, the weights of materials required to obtain the desired concentrations were corrected for moisture content. 


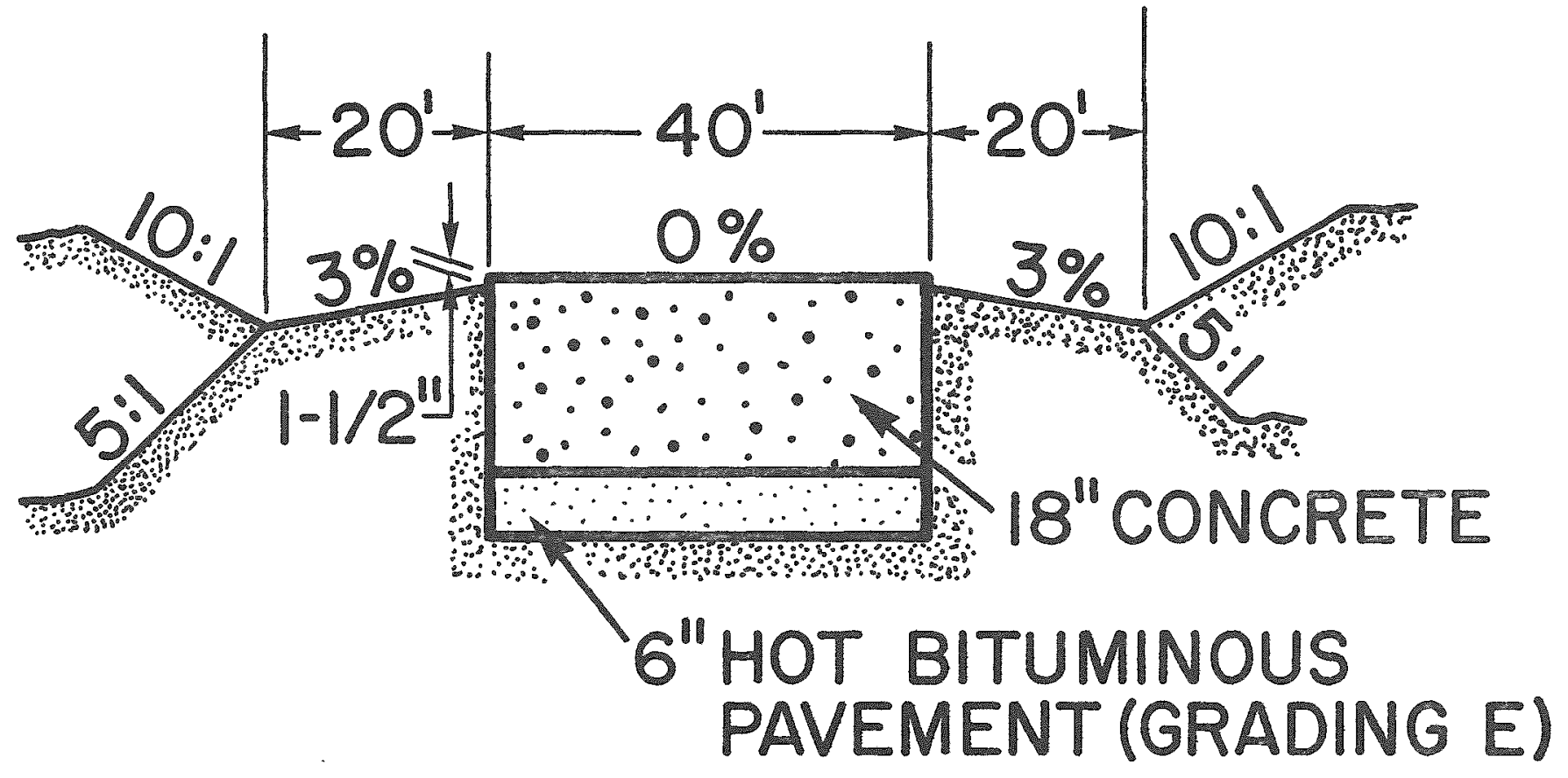

FIGURE

AIRPORT PAD CROSS SECTION 
Masonry sand is the matrix material into which the ores containing the radioelements are blended. The sand is of an average size to pass through a 10 mesh screen; and to improve the homogeneity and particle size of the blended aggregate, the potassium and uranium ores were also crushed to 10 mesh size. The monazite sand containing the thorium element was of correct size and did not require crushing and screening.

To obtain a more consistent and homogeneous blend of materials of grossly different volumes, four separate blending stages were required for each pad as follows:

Stage 1 - Uranium with thorium (in small Tab blender)

Stage 2 - Uranium/thorium with potassium (in large biender)

Stage 3 - Uranium/thorium/potassium with sand (in concrete mixer truck)

Stage 4 - Uranium/thorium/potassium/sand with cement and water (in concrete mixer truck)

Blending was timed to reduce separation of the mixture into fine and coarse factions.

As the blending stage progressed for each pad, the radioactive ore/sand mixture was put into 55-gallon drums, weighed, and separated into lots. Each pad had 10 lots containing approximately 7 cubic yards each. A measured amount of cement was placed with each lot to be added to the aggregate and water when the time came to pour the concrete into forms. When blending of the ore/sand mixture for all pads was completed, the barrels were transported to the facility site at the airport and arranged in lots by pad number at a prepared area.

While the blending activities were taking place, an all-weather gravel road was constructed to the site, 6 inches of asphalt was formed to provide a stable base for the concrete pads, and forms to hold the concrete were constructed on the asphalt base pads. Particular care was exercised in obtaining correct dimensions for the pads and leveling the top of the form.

A small area $(210 \mathrm{ft} \times 20 \mathrm{ft}$ ) of asphalt had been poured near the barrel storage area for hysters to work on when lifting and moving barrels. A sunken ramp had been dug adjacent to the hyster work pad and mixer trucks backed into this ramp so that the hysters could lift the barrels up and pour the aggregate mix into the truck. A water truck parked alongside the ramp provided a water source, and water was measured by flow meter as it was introduced into the mixture. A thick concrete was used to inhibit fine material 
separating out. A uniform consistency was maintained by adding water in an amount necessary to allow a 4-inch slump on a measured cone of wet concrete.

\section{Pouring and Finishing the Pads}

After blending the concrete for a timed interval consistent with proper mixing in the mobile mixer truck, the concrete was poured into the forms. The level of concrete within the forms was maintained as the forms were filled, and each truckload raised the level of concrete in the forms by $1.8 \mathrm{in}$. This procedure insured the consistency of radioactive material over the lateral extent of the pads and decreased the effect of minor discrepancies that may have occurred between each truckload of concrete. A mechanical screeder leveled the concrete with the top of the forms. A brush finish on the surface of the pads was applied by hand.

After the concrete had set for at least 24 hours, grooves $(1 / 4 \mathrm{in} . \times 4 \mathrm{in.})$ were cut in a prescribed pattern across the surface of the pad to control surface cracking. The grooves, which were subsequently filled in with an asphalt base filler, provided avenues of strain release due to contraction or possible future shifting of the pad. Plastic sheets covered the pad during the 24 hour curing period to further reduce surface cracking due to rapid drying of the concrete.

The interconnecting taxiway between the pads was constructed after all pads were in place, and a large asphalt area around pad 5 provides adequate space for an aircraft to turn around and exit the same way it came into the facility. The asphalt in the taxiway is $10 \mathrm{in}$. thick and is designed to support a 30,000-pound aircraft, the approximate weight of a $D C-3$.

\section{PAD CONCENTRATIONS}

The radioelements concentrations for the pads were determined by both chemical and radiometric assays of samples collected as the concrete was poured into the forms. Two sets of samples were collected--one set of 70 samples ( 1 per cubic yard) per pad in one-half gallon ice cream cartons for chemical analysis and another set of 70 samples per pad in 4 in. $\times 21 / 4$ in. aluminum cans for radiometric analysis. The samples collected in cartons were sawed in half so that half could be used for analysis and the other half stored for future reference. The bulk densities of the samples were determined, and the samples were crushed to minus 100 mesh and dried at a temperature of $110^{\circ} \mathrm{C}$ for both radiometric and chemical analysis. The samples caught in aluminum cans were allowed to dry at room temperature for about a week and were then sealed and weighed. 
After being sealed at least 20 days to allow the radon to reach equilibrium, KUT concentrations were determined by gamma-ray spectroscopy. The results of these analyses are presented in Table 2. The concentrations listed are the mean values (and standard deviations) of the analyses performed by radiometric techniques on the 70 samples from each pad. The concentrations are also adjusted to consider the depth of occurrence of the samples within the pads.

The pads at the airport contain 3.95 to 7.47 percent moisture which causes less than a factor of 1.003 reduction in the observed radiometric intensity. This small attenuation effect can usually be neglected because it is smaller than the standard deviation of the reported assays.

\section{CALIBRATION PROCEDURES}

As shown in the aerial photograph (Figure 2), the calibration facility is on the south side of runway 11/29. Aircraft enter the facility from the taxiway and park with the detector positioned above the center of pad 1. This is the background reference pad constructed of concrete containing no radioelements other that those naturally occurring in the sand and cement and which approximates the natural radioactivity of the soil surrounding the pads. An aircrart is positioned in the center of pad 1 to determine the response of the equipment to background. The aircraft then proceeds to park at the center of pads 2,3 , and 4 which contain measured concentrations of potassium, thorium, and uranium with each pad containing one of these elements in a slightly higher concentration than the other pads. Pad 2 is potassium pad, 3 the thorium pad, and 4 contains a relatively higher concentration of uranium. From the count rate data obtained in the energy windows for these elements, stripping ratios and radioelement sensitivities can be determined. The aircraft then taxis to pad 5 to collect data to confirm the accuracy of the calibration data collected on the other four pads. With accurate calibration data, determination of the concentrations in pad 5 should be within acceptable error limits.

\section{OPERATIONAL PROCEDURES}

Bendix Field Engineering Corporation (BFEC), general contractor for DOE-GJO, is responsible for the operation and maintenance of the facility and provides technical liaison with industry users. Correspondence relative to the facility should be addressed as follows:

Bendix Field Engineering Corporation

Field Operations Department/Calibration Section

Box 1569

Grand Junction, Colorado 81501

Phone (303) 242-8621 
Table 2

Airport Pad Concentrations and Densities Walker Field Airport, Grand Junction, Colorado

\begin{tabular}{|c|c|c|c|c|}
\hline \multirow{2}{*}{ PAD } & \multicolumn{3}{|c|}{ CONCENTRATION } & \multirow{2}{*}{ Density } \\
\hline & $\% \mathrm{~K}$ & ppm U & epm Th & \\
\hline 1 & $1.45 \pm 0.01$ & $2.2 \pm 0.1$ & $6.3 \pm 0.1$ & $1.91 \pm 0.00$ \\
\hline 2 & $5.74 \pm 0.09$ & $5.1 \pm 0.3$ & $8.5 \pm 0.3$ & $2.00 \pm 0.01$ \\
\hline 3 & $2.01 \pm 0.04$ & $5.1 \pm 0.2$ & $45.3 \pm 0.7$ & $1.92 \pm 0.00$ \\
\hline 4 & $2.03 \pm 0.05$ & $30.3 \pm 1.6$ & $9.2 \pm 0.3$ & $1.91 \pm 0.00$ \\
\hline 5 & $4.11 \pm 0.06$ & $20.4 \pm 1.3$ & $17.5 \pm 0.3$ & $1.97 \pm 0.00$ \\
\hline
\end{tabular}

Note: Statistical uncertainties quoted are the 95 percent confidence intervals. 
Companies desiring to calibrate gamma-ray spectrometers or other surface radiation detection equipment can obtain permission for free use of the facility by contacting BFEC at the above address. A key to the facility road, required for vehicle usage, will be provided to a responsible company representative. Usage appointments can be obtained by mail or phone but should be scheduled through BFEC to prevent unnecessary delays in getting on the pads or undue congestion at the facility. Usage priority will be given to those with scheduled appointments.

Aircraft personnel will comply with the following regulations:

1. Follow accepted landing, taxiing, and take-off procedures.

2. Request tower permission to enter or leave facility.

3. Do not occupy the facility for any purpose other than for calibration.

4. Radio transmissions are limited to normal communication with the tower.

5. Do not park on the taxiway between the main taxiway and pad 1.

6. Remain on the concrete pads or asphalt taxiway at all times.

7. Do not enter the facility if another plane is already on the pads.

8. The pilot will advise the tower where he can be reached if he leaves the immediate vicinity of the aircraft.

9. Calibration will be completed expeditiously and in a manner consistent with the requirements of the detector system.

Vehicle personnel will comply with the following regulations:

1. Enter and leave the facility via the access road and lock all gates after each pass through.

2. Do not enter the airport taxiway or runway without radio control or without expressed permission from the tower. Failure to comply with this regulation could result in legal action and would result in loss of the privilege to use the facility.

3. Remain on the pads or asphalt taxiway. Parking space is provided on the graveled area south of pad 5.

4. Do not enter the facility if a plane is on the pads or taxiway.

\section{ENVIRONMENTAL CONSIDERATIONS}

Because the pads contain radioactive ores, a survey was conducted to determine the exposure levels to which personnel working at the facility 
would be subjected. An ionization chamber, designed and fabricated specifically for this type of effort by the Health and Safety Laboratory of the U.S. Department of Energy, was used as the primary instrument in the survey. Dose equivalent values in units expressed as milij-Roentgens per hour (mR/hr) were assigned to 352 grid points located at $25 \mathrm{ft}$ intervals across the facility. Ground level observations, collected with a hand-held gamma-ray scintillation counter and recorded in counts per second (CPS), are also included on the Environmental Radiometric Survey map (Figure 5).

Exposure rates were recorded at the center of each of the five pads to provide the maximum equivalent dose rate for each pad as follows:

Pad $1-0.016 \mathrm{mR} / \mathrm{hr}$ (normal background)

Pad $2-0.027 \mathrm{mR} / \mathrm{hr}$

Pad $3=0.025 \mathrm{mR} / \mathrm{hr}$

Pad $4-0.028 \mathrm{mR} / \mathrm{hr}$

Pad $5=0.031 \mathrm{mR} / \mathrm{hr}$

Title 10, Part 20.105 of the Code of Federal Regulations regarding the permissible levels of radiation in unrestricted areas, sets forth limits "not likely to cause any individual to receive a dose to the whole body in any period of one calendar year in excess of 0.5 rem; radiation levels which, if an individual were continuously present in the area, could result in his receiving a dose in excess of two millirems in any one hour. or radiation levels which, if an individual were continuously present in the area, could result in his receiving a dose in excess of 100 millirems in any seven consecutive days."

For gamma-ray and $x$-ray radiation, 1 millirem is equal to 1 milliRoentgen. Continuous exposure to the radiation on any of the airport pads for seven consecutive days will produce a dose of less than 6 millirems. This is well below the maximum permissible level of 100 millirems.

NOTICE TO CORPORATE OF INDIVIDUAL USERS OF THIS FACILITY

The U.S. Department of Energy, Bendix Field Engineering Corporation, and the Walker Field Airport Authority shall not accept any responsibility for surface vehicles, aircraft, or personnel involved in the use or occupation of the calibration facility or its environs. 


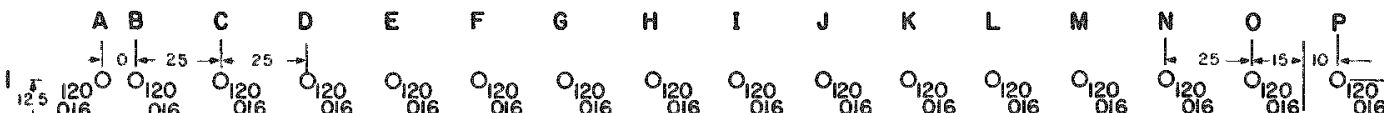

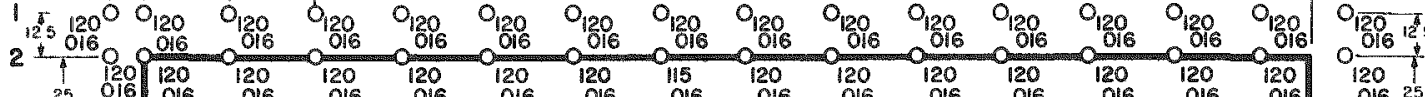

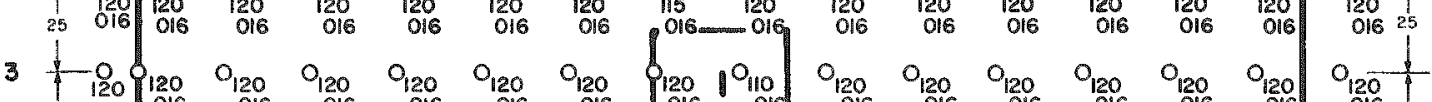

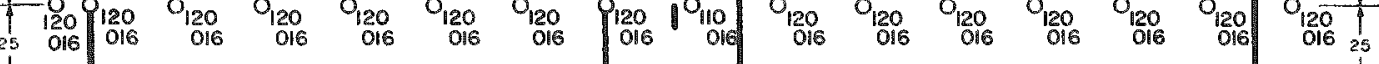

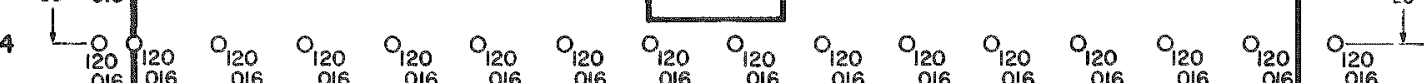

016 O16 016 016 $016 \quad 016$

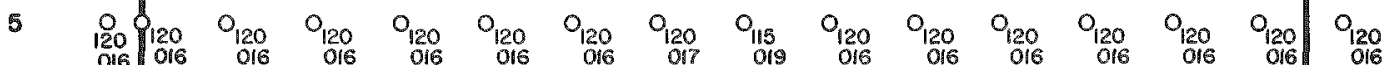

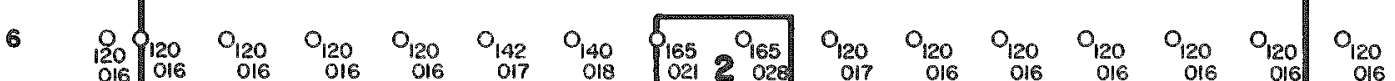

$\begin{array}{llllllllllllll}016 & 016 & 016 & 017 & 016 & 016 & 016 & 016 & 016 & 016\end{array}$

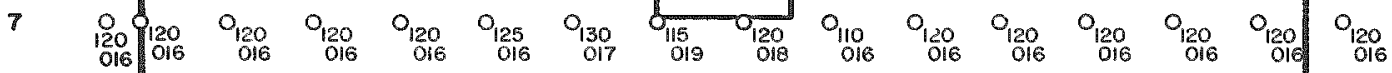

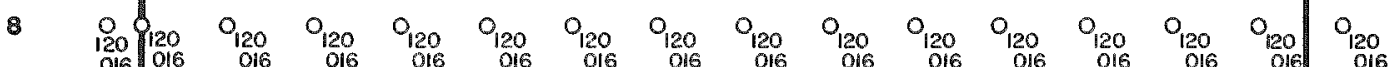

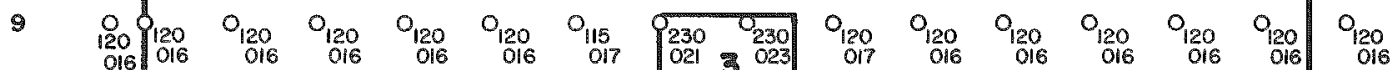

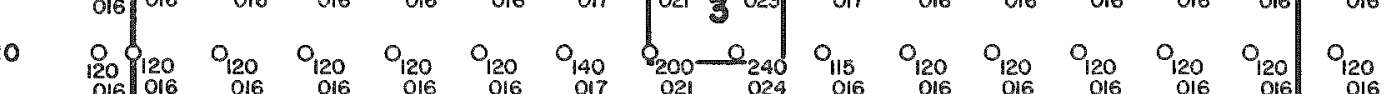

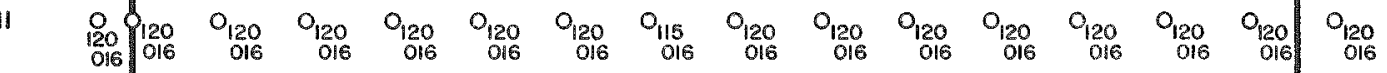

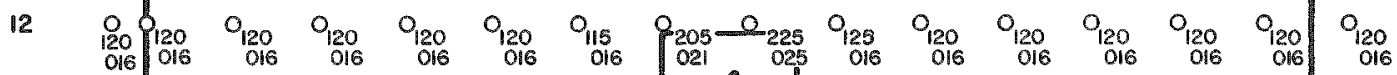

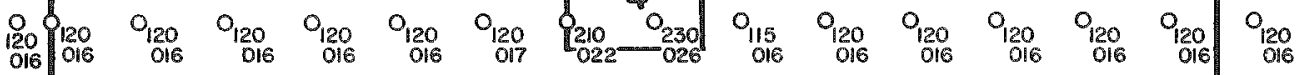

14

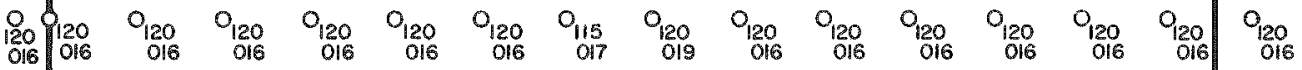

15

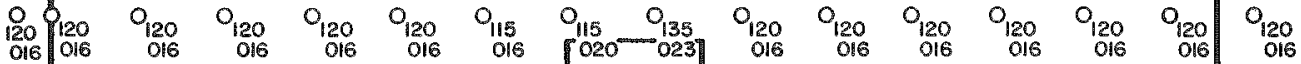

16

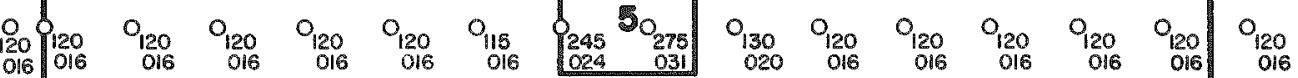

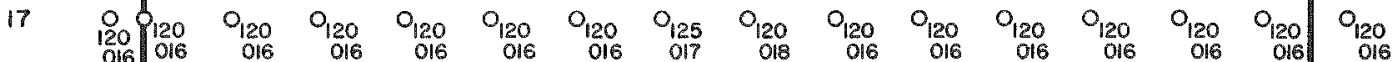

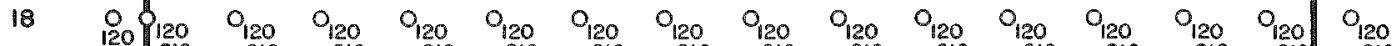

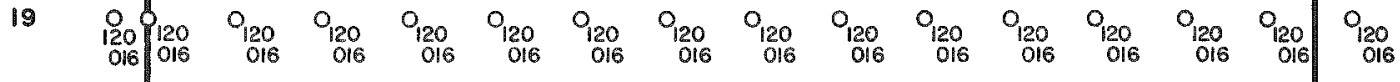

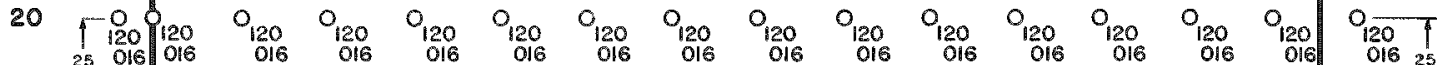
$\begin{array}{llllllllllllllll}f_{120} & 0_{120} & 0_{120} & 0_{120} & 0_{120} & 0_{120} & 0_{120} & 0_{120} & o_{120} & 0_{120} & 0_{120} & 0_{120} & 0_{120} & 0_{120} & 0_{120}\end{array}$

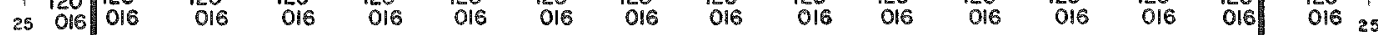

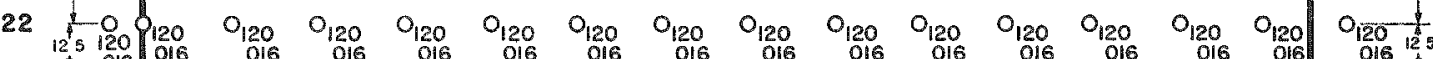

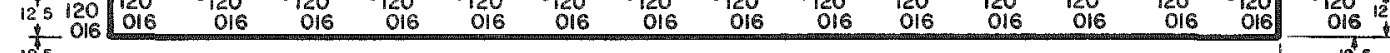

23

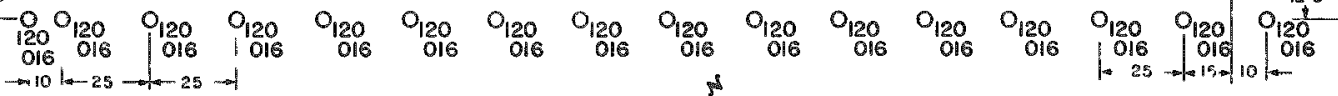

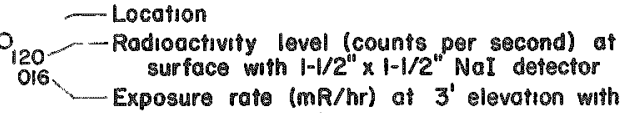

EXPLANATION ionization chamber

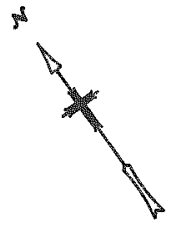

FIGURE 5

AIRPORT CALIBRATION PADS

WALKER FIELD AIRPORT, GRAND JUNCTION, COLORADO 


\section{APPENDICES}

A. Mineralogic and Petrologic Analyses............. R. Allen

B. Material Weights and Blending Procedures........... L. Bruner

C. Photographic Review of Construction Activities....D. L. Ward 


\section{APPENDIX A}

MINERALOGIC AND PETROLOGIC ANALYSIS

\section{CONTENTS}

$$
\begin{array}{ll}
\text { SAMPLE } 19726 \text { - Sand } & \frac{\text { Page }}{A^{-}-2} \\
\text { SAMPLE } 19727 \text { - K-feldspar } & \text { A-5 } \\
\text { SAMPLE } 19289 \text { - Monazite Sand } & \text { A-7 } \\
\text { SAMPLE } 18290 \text { - Schwartzwalder Ore A-9 }
\end{array}
$$


Sample 19726 - Sand

Sample 19726 is a medium grained (Table 2) sand consisting of angular to subrounded fragments of volcanic rocks, sedimentary rocks, chert, quartz, plutonic rocks, K-feldspar and plagioclase (Table 1). The volcanic rock fragment suite consists mainly of fresh basalt porphyry fragments with lesser amounts of andesite porphyry and other extremely altered porphyritic rocks. The sedimentary rock fragments consist of siltstone and claystone and sparse limestone. Chert, polycrystalline quartz, and single crystals of quartz are present in that order of abundance. The plutonic rock fragments consist of quartz and altered feldspar and mafic minerals. Minor amounts of K-feldspar and plagioclase, both altered to clay and serecite are present.

A heavy mineral separation using bromoform (Specific Gravity 2.85) was completed, and the results are presented in Table 3.

\section{Table 1}

Semiquantitative Modal Analys is

$$
\text { Sample } 19726 \text { - Sand }
$$

Mineral/component

Volcanic Rock Fragments

Sedimentary Rock Fragments

Chert

Quartz

Plutonic Rock Fragments

K-Feldspar

Plagioclase
Percent

47

20

13

9

8

2

1 
Table 2

Sieve Analysis

Sample 19726 - Sand

\begin{tabular}{|c|c|c|c|c|c|c|}
\hline $\begin{array}{l}\text { Screen mesh } \\
\text { U.S. Series }\end{array}$ & $\begin{array}{l}\text { Size opening } \\
\text { millimeters }\end{array}$ & $\begin{array}{l}\text { phi } \\
\text { units }\end{array}$ & $\begin{array}{l}\text { Weight } \\
\text { retained (gm) }\end{array}$ & $\begin{array}{l}\text { Cumulative } \\
\text { weight (gm) }\end{array}$ & $\begin{array}{l}\text { Percent } \\
\text { retained }\end{array}$ & $\begin{array}{l}\text { Cumulative } \\
\text { percent }\end{array}$ \\
\hline 5 & 4.0 & -2 & 0 & 0 & 0 & 0 \\
\hline 10 & 2.0 & -1 & 4.3 & 4.3 & 6.63 & 6.63 \\
\hline 18 & 1.0 & 0 & 9.5 & 13.8 & 14.64 & 21.26 \\
\hline 35 & 0.5 & 1 & 16.0 & 29.8 & 24.65 & 45.92 \\
\hline 60 & 0.25 & 2 & 26.1 & 55.9 & 40.22 & 86.13 \\
\hline 120 & 0.125 & 3 & 7.7 & 63.6 & 11.86 & 98.00 \\
\hline 230 & 0.0625 & 4 & 1.1 & 64.7 & 1.69 & 99.69 \\
\hline 325 & 0.0440 & 4.5 & 0.1 & 64.8 & 0.15 & 99.85 \\
\hline Pan & $<0.0440$ & $<4.5$ & 0.1 & 64.9 & 0.15 & 100.00 \\
\hline
\end{tabular}


Table 3

$$
\begin{aligned}
& \text { Heavy Mineral Analysis } \\
& \text { Sample } 19726 \text { - Sand }
\end{aligned}
$$

Mineral

Magnetite

Hornblende

Biotite

Olivine

Epidote

IImenite

Garnet

Limonite

Hematite

Muscovite

Tourmaline

Percent separated

by bromoform

\section{Percent in Heavy Fraction}

35

20

15

10

5

5

3

3

2

1

1

2.67 
Sample 19727 - K-feldspar

This sample consists mainly of microcline perthite, with minor amounts of quartz, muscovite and plutonic rock fragments (Table 4). The microcline perthite fragments are rather coarse (Table 5) cleavage fragments. Most of the fragments display a coarsely perthitic texture and the characteristic gridiron twinning of microcline. The composition of the plagioclase in the perthite was not determined. A few grains have flakes of muscovite attached to them. Muscovite also occurs as separate grains. The sparse plutonic rock fragments are rather fine grained rocks of granite composition. No minerals of specific gravity $>2.85$ were found in this sample.

Table 4

Semiquantitative Modal Analysis

Sample 19727 K-feldspar

Mineral/component

Microcline Perthite

Quartz

Igneous Rock Fragments

Muscovite
Percent 96

2

1

1 
Table 5

Sieve Analysis

Sample 19727 - K-feldspar

\begin{tabular}{|c|c|c|c|c|c|c|}
\hline $\begin{array}{l}\text { Screen mesh } \\
\text { U.S. Series } \\
\end{array}$ & $\begin{array}{l}\text { Size opening } \\
\text { millimeters }\end{array}$ & $\begin{array}{l}\text { phi } \\
\text { units }\end{array}$ & $\begin{array}{l}\text { Weight } \\
\text { retained }(\mathrm{gm})\end{array}$ & $\begin{array}{l}\text { Cumulative } \\
\text { weight (gm) }\end{array}$ & $\begin{array}{l}\text { Percent } \\
\text { retained }\end{array}$ & $\begin{array}{l}\text { Cumulative } \\
\text { percent }\end{array}$ \\
\hline 5 & 4.0 & -2 & 0 & 0 & 0 & 0 \\
\hline 10 & 2.0 & -1 & 9.6 & 9.6 & 33.92 & 33.92 \\
\hline 18 & 1.0 & 0 & 11.9 & 21.5 & 42.05 & 75.97 \\
\hline 35 & 0.5 & 1 & 3.2 & 24.7 & 11.31 & 87.28 \\
\hline 60 & 0.25 & 2 & 1.8 & 26.5 & 6.36 & 93.64 \\
\hline 120 & 0.125 & 3 & 0.9 & 27.4 & 3.18 & 96.82 \\
\hline 230 & 0.0624 & 4 & 0.4 & 27.8 & 1.41 & 98.23 \\
\hline 325 & 0.0440 & 4.5 & 0.3 & 28.1 & 1.06 & 99.29 \\
\hline Pan & $<0.0440$ & $<4.5$ & 0.2 & 28.3 & 0.71 & 100.00 \\
\hline
\end{tabular}


Sample 19289 - Monazite sand

This sample is a fine (Table 7) sand consisting of angular to rounded grains of monazite, opaques (mainly ilmenite), quartz, limonite, sphene, and sedimentary rock fragments (Table 6). The coarser grains are generally less rounded and less spherical than the finer grains. Monazite occurs as both rounded (commonly spherical) and as euhedral grains. The opaque grains are generally more angular than the other components. 11 menite is the predominate opaque mineral but magnetite and hematite are also present. Quartz occurs as medium, monocrystalline grains. Limonite occurs as rounded, fine grains and also as coatings and fracture fillings on the other components. Approximately 97 percent (by weight) of the sample was recovered in the heavy fraction (specific gravity $>2.85$ ) leaving mainly quartz in the light fraction.

\section{Table 6}

Semiquantitative Modal Analysis

$$
\text { Sample } 18289 \text { - Monazite Sand }
$$

Minera / component

Monazite

Opaque ${ }^{1}$

Quartz

Limonite

Tourmaline

Sphene

Sedimentary Rock Fragments

Zircon

1Predominantly ilmenite

\section{Percent}

67

18

8

2

2

2

1

TR 
Table 7

Sieve Analysis

Sample 18289 - Monazite Sand

\begin{tabular}{|c|c|c|c|c|c|c|}
\hline $\begin{array}{l}\text { Screen Mesh } \\
\text { U.S. Series }\end{array}$ & $\begin{array}{l}\text { Size opening } \\
\text { millimeters }\end{array}$ & $\begin{array}{l}\text { phi } \\
\text { units }\end{array}$ & $\begin{array}{l}\text { Weight } \\
\text { retained (gm) }\end{array}$ & $\begin{array}{l}\text { Cumulative } \\
\text { weight (gm) }\end{array}$ & $\begin{array}{l}\text { Percent } \\
\text { retained }\end{array}$ & $\begin{array}{l}\text { Cumulative } \\
\text { percent }\end{array}$ \\
\hline 5 & 2.0 & -2 & 0 & 0 & 0 & 0 \\
\hline 10 & 4.0 & -1 & 0 & 0 & 0 & 0 \\
\hline 18 & 1.0 & 0 & 1.1 & 1.1 & 0.37 & 0.37 \\
\hline 35 & 0.5 & 1 & 12.8 & 13.9 & 4.32 & 4.69 \\
\hline 60 & 0.25 & 2 & 55.7 & 69.6 & 18.78 & 23.47 \\
\hline 120 & 0.125 & 3 & 135.0 & 204.6 & 45.52 & 68.98 \\
\hline 230 & 0.0625 & 4 & 81.7 & 286.3 & 27.55 & 96.53 \\
\hline 325 & 0.0440 & 4.5 & 6.9 & 293.2 & 2.33 & 98.85 \\
\hline Pan & $<0.0440$ & $<4.5$ & 3.4 & 296.6 & 1.15 & 100.00 \\
\hline
\end{tabular}


Sample 18290 - Schwartzwalder Ore

This sample consists of angular to subangular fragments containing calcite, quartz, K-feldspar, muscovite, uraninite, pyrite, and hematite (Table 8). Some fragments are monomineralic but most contain several minerals. The sample is coarser than the other samples but the actual percentage of fines is probably greater than indicated in the sieve analysis (Table 9) because the fine fraction is very cohesive and tends to stick to the coarser particles.

Calcite is generally fine grained with some sparite present. It forms the matrix surrounding most of the other minerals. Quartz occurs as subangular, monocrystalline grains and as fine intergrowths with calcite. K-feldspar, both orthoclase and microcline, occurs as fresh subhedral grains In some of the fragments. Scattered flakes of muscovite are present. Uraninite (Table 10), pyrite, and hematite occur as scattered grains and bands. Many fragments contain these opaque minerals as a matrix making up to 90 percent of the fragments.

The texture of individual fragments ranges from granular to schistose. Calcite and the opaque minerals are generally replacements of earlier formed minerals but it is difficult to see the whole plcture because of the fragmental nature of the sample.

A heavy mineral separation using bromoform (specific gravity 2.85) was performed. The heavy fraction (29.8 percent of the sample) consists of those fragments rich in uraninite, pyrite, and hematite. 


\section{Table 8}

Semiquantative Modal Analysis

Sample 18290 - Schwartzwalder Ore

Minera1/component

Calcite

Quartz

K-feldspar

Muscovite

Uraninite

Pyrite

Hematite
Percent

38

36

9

6

5

4

2 
Table 9

Sieve Analysis

Sample 18290 - Schwartzwalder Ore

\begin{tabular}{|c|c|c|c|c|c|c|}
\hline $\begin{array}{l}\text { Screen Mesh } \\
\text { U.S. Series } \\
\end{array}$ & $\begin{array}{l}\text { Size opening } \\
\text { millimeters }\end{array}$ & $\begin{array}{l}\text { phi } \\
\text { units }\end{array}$ & $\begin{array}{l}\text { Weight } \\
\text { retained (gm) }\end{array}$ & $\begin{array}{l}\text { Cumulative } \\
\text { weight (gm) }\end{array}$ & $\begin{array}{l}\text { Percent } \\
\text { retained }\end{array}$ & $\begin{array}{l}\text { Cumulative } \\
\text { percent }\end{array}$ \\
\hline 5 & 2.0 & -2 & 0 & 0 & 0 & 0 \\
\hline 10 & 4.0 & -1 & 12.1 & 12.1 & 9.98 & 9.98 \\
\hline 18 & 1.0 & 0 & 40.4 & 52.5 & 33.33 & 43.32 \\
\hline 35 & 0.5 & 1 & 31.5 & 84.0 & 25.99 & 69.31 \\
\hline 60 & 0.25 & 2 & 15.2 & 99.2 & 12.54 & 81.85 \\
\hline 120 & 0.125 & 3 & 19.6 & 118.8 & 16.17 & 98.42 \\
\hline 230 & 0.0625 & 4 & 1.7 & 120.5 & 1.40 & 99.42 \\
\hline 325 & 0.0440 & 4.5 & 0.3 & 120.8 & 0.24 & 99.67 \\
\hline Pan & $<0.0440$ & $<4.5$ & 0.4 & 121.2 & 0.33 & 100.00 \\
\hline
\end{tabular}


Table 10

X-ray Powder Diffraction Comparison

Uranium Mineral

Sample 18290

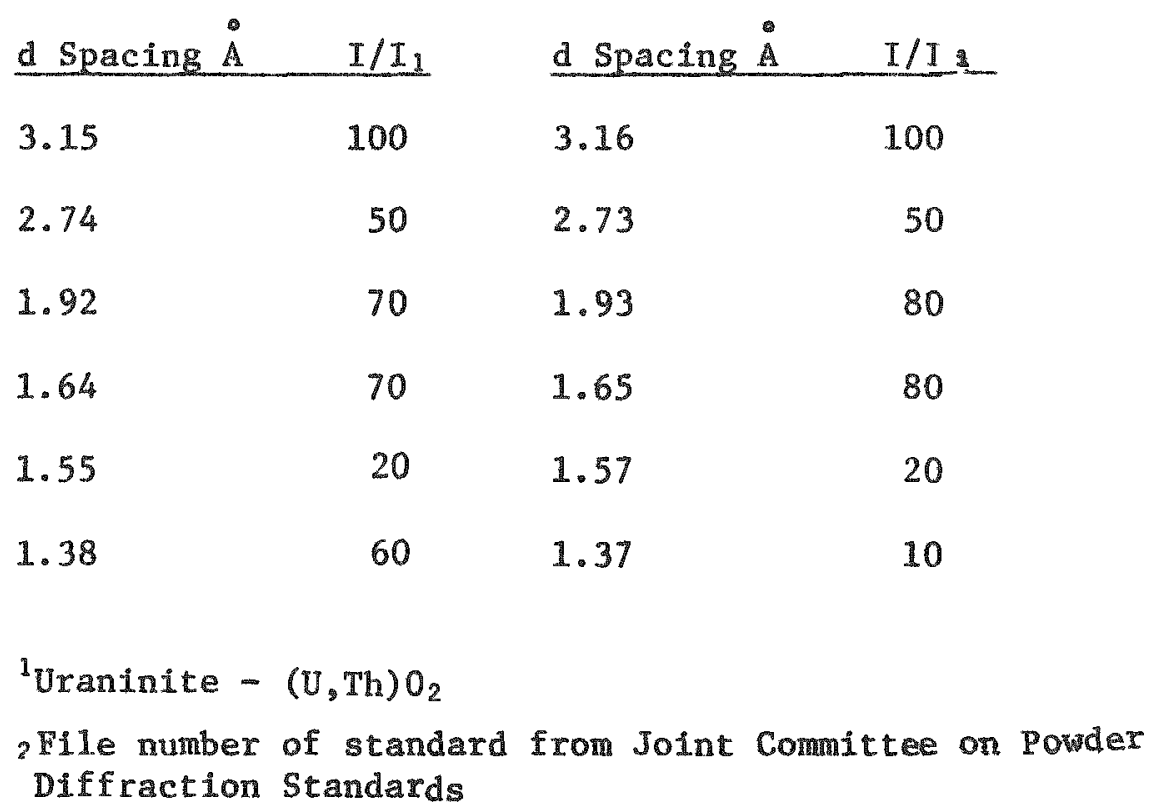

Uraninite $5-0549^{2}$ 


\section{APPENDIX B}

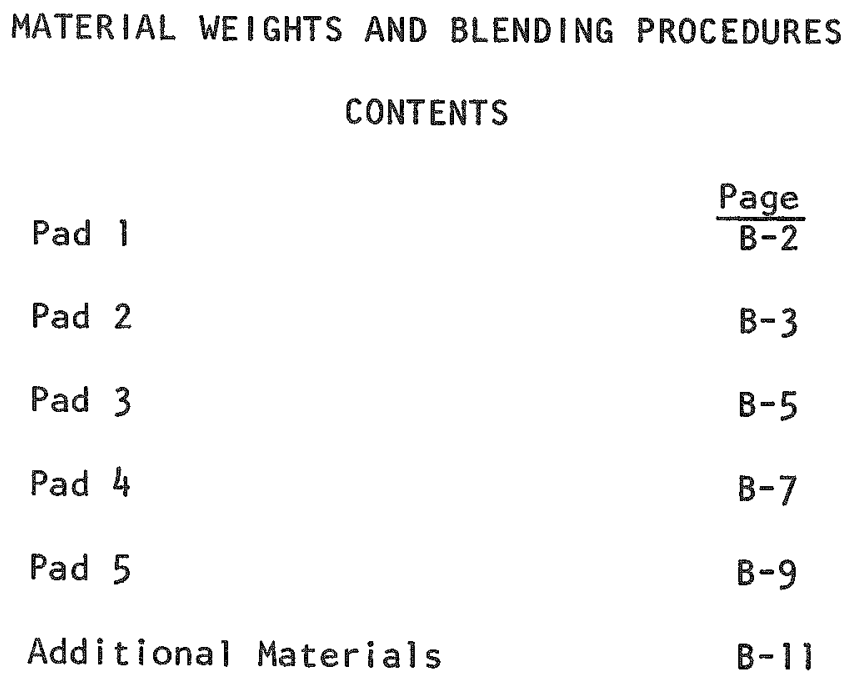

B-1 
Revised Weights

\begin{tabular}{lcccc}
\hline Material & $\%$ of lot & $\begin{array}{c}\text { Wet Weight } \\
\text { lbs }\end{array}$ & $\%$ Moisture & $\begin{array}{c}\text { Dry Weight } \\
\text { Ibs }\end{array}$ \\
\hline Sand & 75.58 & 160,825 & 3.00 & 156,000 \\
TOTALS & 75.58 & 160,825 & 3.00 & 156,000 \\
Cement & 24.42 & 51,950 & $-0-$ & 51,950 \\
TOTALS & 100.00 & 212,775 & 2.27 & 207,950 \\
\hline
\end{tabular}

\section{COMPOSITED AS FOLLOWS}

Lotted in 10 lots Wet weight per lot $21,277.5 \mathrm{lbs}$

$$
\begin{aligned}
& \text { Each lot to contain } 23 \text { drums of sand } \\
& 9 \text { drums of cement } \\
& 32 \text { total no. of drums per lot }
\end{aligned}
$$

\section{BLENDING PROCEDURES}

No blending required. The sand and cement will be placed in separate 55 gallon open head drums. Each drum will be tagged with the following information:

PAD NO.

LOT NO.

DRUM NO.

Designate" $\mathrm{C}$ " or "A" after drum number to indicate drum contains "cement" or "aggregate". 
Revised Weights

\begin{tabular}{lrrrr}
\hline Material & $\%$ of lot & $\begin{array}{c}\text { Wet Weight } \\
\text { lbs }\end{array}$ & $\%$ Moisture & $\begin{array}{r}\text { Dry Weight } \\
\text { lbs }\end{array}$ \\
\hline Feldspar & 58.46 & 125,582 & 0.09 & 125,469 \\
Sand & 16.68 & 35,825 & 3.00 & 34,750 \\
Uranium ore & 0.007 & 16 & $-0-$ & 16 \\
Thorium ore & 0.016 & 35 & $-0-$ & 35 \\
$\quad$ TOTALS & 75.17 & 161,458 & 0.74 & 160,270 \\
Cement & 24.83 & 53,345 & $-0-$ & 53,345 \\
\multicolumn{1}{c}{ TOTALS } & 100.00 & 214,803 & 0.55 & 213,615 \\
\hline
\end{tabular}

\section{COMPOSITED AS FOLLOWS}

Lotted in 10 lots

Each lot to contain 22 drums of composited aggregate

Wet weight per lot $21,480.37 \mathrm{bs}$

9 drums of cement

31 total no. of drums per lot

\section{BLENDING PROCEDURES}

Blend sand, uranium, and thorium in large blender for 10 minutes. Place blended sample in barrels marked Pad No., Lot No., Drum No., and Weight. This sample will then be blended with the feldspar portion of the lot in a Redi-mix truck for 10 minutes. This sample will then be placed in 55 gallon open head drums. Each drum will be tagged with the following information:

PAD NO.

LOT NO.

DRUM NO.

Designate " $C$ " or " $A$ " after drum No. to indicate drum contains cement or aggregate.

Handling instructions as follows: 
Step 1 -- Combine 16 lbs uranium, 35 lbs thorium, and blend for 15 minutes. The 51 lbs blended material divided by weight to 50 equal parts ( 462.67 grams) will be placed in glass jars and marked "PAD 2". Store until sand portion of lot is ready to blend.

Step 2 -- Weigh out 50 drums of sand at 716.5 lbs which equals 35,825 Ibs. Combine each drum with 1 jar of above sample (462.67 grams) and blend for 10 minutes in $10 \mathrm{cu} f t$ blender. Blended material is then placed in 55 gallon open head drums, weighed, tagged and divided into 10 lots. Tag shows "PAD 2 Sand-U-T", Lot No., Drum No., and Weight.

Step 3 -- Weigh 125,582 lbs feldspar into 10 equal parts of $12,558.2$ lbs. Each of the 10 portions will be stacked with the sand, uranium, and thorium mix. Tag "FELDSPAR PAD 2, LOT NO. , DRUM NO.

Step 4 -- The uranium, thorium, and sand mix and feldspar will then be dumped into a Redi-mix truck and mixed 10 minutes. This mix will be discharged into the number of drums required, and tagged "PAD 2, LOT NO. DRUM NO. .1

NOTE: - - All drum weights will be recorded on weigh out sheet. Keep all drums in their respective lots.

LOT CONTAINS:

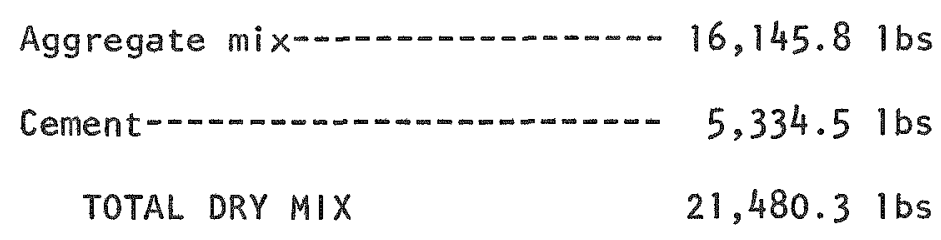

Multiply above figures by 10 to obtain pad figures. 
Revised Weights

\begin{tabular}{lcccc}
\hline Material & $\%$ of lot & $\begin{array}{c}\text { Wet Weight } \\
\text { ibs }\end{array}$ & $\begin{array}{c}\% \text { Moisture } \\
\text { (Approx) }\end{array}$ & $\begin{array}{c}\text { Dry Weight } \\
\text { lbs }\end{array}$ \\
\hline $\begin{array}{l}\text { Feldspar } \\
\text { Sand }\end{array}$ & 8.80 & 19,184 & 0.52 & 19,084 \\
Uranium ore & 66.63 & 145,307 & 3.00 & 140,948 \\
Thorium ore & 0.003 & 7 & $-0-$ & 7 \\
TOTALS & 0.106 & 231 & $-0-$ & 231 \\
Cement & 75.54 & 164,729 & 2.71 & 160,270 \\
TOTALS & 24.46 & 53,345 & $-0-$ & 53,345 \\
& 100.00 & 278,074 & 2.04 & 213,615 \\
\hline
\end{tabular}

COMPOSITED AS FOLLOWS:

Lotted in 10 lots

Wet weight per lot $21,807.4$ lbs

Each Lot Contains 23 drums of composited aggregated

9 drums of cement

32 tetal no. of drums per lot

BLENDING PROCEDURES

Blend feldspar, uranium, and thorium in large blender for 10 minutes. Place blended sample in barrels marked Pad No., Lot No., Drum No., and Weight. This sample will then be blended with sand portion of the lot in a Redi-mix truck for 10 minutes. Fhis sample will then be placed in 55 gallon open head drums. Each drum will be tagged with the following information:

PAD NO.

LOT NO.

DRUM NO.

Designate" $C$ " or "A" after drum No. to indicate drum contains cement or aggregate. Handling instructions as follows: 
Step 1 - Combine 7 lbs uranium and 231 lbs thorium and blend for 15 minutes. The 238 ibs of blended material will be divided into 30 equal parts (7.93 lbs) and placed in glass jars marked "PAD $3 "$. These are stored until the feldspar portion is ready to blend.

Step 2 -- Weigh out 30 drums of feldspar at 639.47 lbs which equals 19,184 1bs. Combine each drum with one jar of the above sample $(7.93 \mathrm{lbs})$ and blend for 10 minutes in the $10 \mathrm{cu} f t$ blender. Blended material is then placed in 55 gallon open head drums, weighed, tagged and divided into 10 lots. Tags will show "PAD 3", Feldspar-U-T, Lot No., Drum No., and Weight.

Step 3 - 145,307 lbs of sand will be weighed into 10 equal parts of $14,530.7$ Ibs. Each of the 10 portions will be stacked with the feldspar, uranium, and thorium mix. Tag with "PAD 3", LOT NO., DRUM NO., WEIGHT and mark "SAND".

Step 4 - - The feldspar, uranium, and thorium mix will be added along with the sand to a Redi-Mix truck and mixed for a minimum of 10 minutes. This mix will be discharged into the required number of drums and tagged: PAD 2, LOT NO., and DRUM NO.

NOTE: All drum weights will be recorded on weigh out sheet. Keep all drums in their respective lots.

LOT CONTAINS:

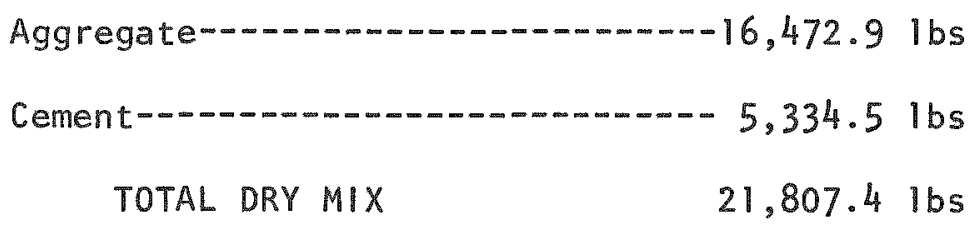

Multiply above figures by 10 to obtain pad figures. 
Revised Weights

\begin{tabular}{lrrrr}
\hline Material & \% of llot & $\begin{array}{c}\text { Wet Weight } \\
\text { lbs }\end{array}$ & \%oisture & $\begin{array}{c}\text { Dry Weight } \\
\text { Ibs }\end{array}$ \\
\hline Feldspar & 8.68 & 18,428 & .15 & 18,900 \\
Sand & 66.71 & 145,429 & 3.00 & 141,066 \\
Uranium ore & 0.13 & 285 & $-0-$ & 285 \\
Thorium ore & 0.009 & 19 & $-0-$ & 19 \\
$\quad$ TOTALS & 75.53 & 164,661 & 2.67 & 160,270 \\
Cement & 24.47 & 53,345 & $-0-$ & 53,345 \\
TOTALS & 100.00 & 218,006 & 2.01 & 213,615 \\
\hline
\end{tabular}

\section{COMPOSITED AS FOLLOWS}

Lotted in 10 lots Wet weight per lot $21,800.6$ 1bs

Each lot to contain 23 drums of composited aggregate

9 drums of cement

32 total no. of drums per lot

\section{BLENDING PROCEDURES}

Blend feldspar, uranium, and thorium in large blender for 10 minutes. Place blended sample in barrels marked "PAD No., Lot No., Drum No., and Weight". This sample will be blended with the sand portion of the lot in a Redi-mix truck for 10 minutes; then place in 55 galion open head drums. Each drum will be tagged with the following information:

PAD NO.

LOT NO.

DRUM NO.

Designate " $C$ " or " $A$ " after drum no. to indicate drum contains cement or aggregate.

Handling instructions as follows: 
Step 1 -- Combine 285 lbs uranium ore and $191 \mathrm{lbs}$ of thorium ore and blend for 15 minutes. The 304 lbs of blended material will be divided into 30 equal parts $(10.13$ lbs) and placed in glass jars marked "PAD 4". These are stored until the feldspar portion is ready to blend.

Step 2 -- Weigh out 30 drums of feldspar at 630.93 ibs which totals 18,928 Ibs. Combine each drum with one jar of the above sample (10.13 ibs) and blend for 15 minutes in the $10 \mathrm{cu} f t$ blender. Blended material is then placed in 55 gallon open head drums, weighed, tagged and divided into 10 lots. Tags will show "PAD 4, Feldspar-U-T Mix", Lot No., Drum No. and Weight.

Step $3--145,429$ lbs of sand will be divided into 10 equal parts of $14,542.9$ lbs. Each of the 10 portions will be stacked with the feldspar, uranium, and thorium mix. Tag with "PAD 4, LOT NO., DRUM NO., SAND and WEIGHT".

Step 4 -- The feldspar, uranium, and thorium mix will be added along with the sand to a Redi-Mix truck and mixed for a minimum of 10 minutes. This mix will be discharged into the required number of drums and tagged: "PAD 4, LOT NO., and DRUM NO."

NOTE: All drum weights will be recorded on weigh out sheet. Keep all drums in their respective lots.

LOT CONTAINS:

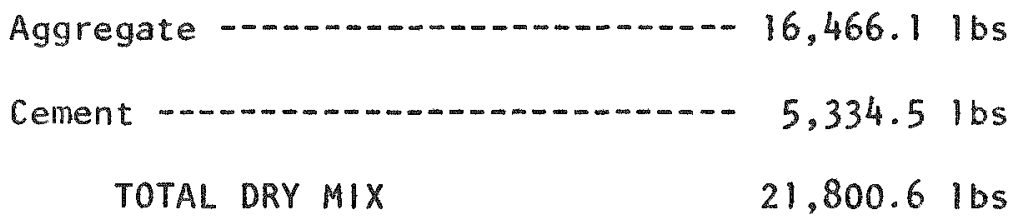

Multiply above figures by 10 to obtain pad figure. 
Pad 5

TYPE MIX

Revised Weights

\begin{tabular}{lcrcr}
\hline Material & $\%$ of lot & $\begin{array}{c}\text { Wet Weight } \\
\text { lbs }\end{array}$ & \% Moisture & $\begin{array}{r}\text { Dry Weight } \\
\text { lbs }\end{array}$ \\
\hline Feldspar & 42.07 & 90,823 & 0.15 & 90,687 \\
Sand & 33.10 & 71,457 & 3.00 & 69,373 \\
Uranium ore & 0.087 & 188 & $-0-$ & 188 \\
Thorium ore & 0.038 & 82 & $-0-$ & 82 \\
$\quad$ TOTALS & 75.30 & 162,550 & 1.40 & 160,270 \\
Cement & 24.71 & 53,345 & $-0-$ & 53,345 \\
\multicolumn{1}{c}{ TOTALS } & 100.00 & 215,895 & 1.06 & 213,615 \\
\hline
\end{tabular}

\section{COMPOSITED AS FOLLOWS}

Lotted in 10 lots

Net weight per lot $21,589.5$ lbs

Each lot to contain 23 drums of composited aggregate

9 drums of cement

32 total no. of drums per lot

\section{BLENDING PROCEDURES}

Blend sand, uranium, and thorium in Redi-Mix cement truck for 10 minutes. This sample will then be blended with the feldspar portion of the lot in the Redi-Mix cement truck for an additional 10 minutes. The sample will then be placed in 55 gallon open head drums. Each drum will be tagged with the following information:

PAD NO.

LOT NO.

DRUM NO.

Designate " $C$ " or "A" after drum no. to indicate drum contains cement or aggregate. Handling instructions as follows: 
Step 1 -- Combine 188 Ibs of uranium ore and 82 Ibs of thorium ore and blend for 15 minutes. The 270 lbs of blended material will be divided into 10 equal parts $(27.0 \mathrm{lbs})$ and placed in clean sample sacks. Each sack will be tagged with "PAD 5 " and will be held until the sand mix.

Step $2--71,457$ lbs of sand will be divided into 10 equal parts of $7,145.7$ Ibs. Each of the 10 portions will be stacked separately and tagged "PAD 5, LOT NO., DRUM NO., WEIGHT and SAND".

Step $3-90,823$ lbs of feldspar will be divided into 10 equal parts of $9,082.3$ lbs. These drums will be stacked near, but kept separate from the sand aggregate. Drums will be tagged same as above and marked "Feldspar".

Step 4 -- The Redi-Mix truck will be charged with the sand lot first. Sand drums will be opened and a portion of the 27.0 lbs of uranium and thorium mix placed into each drum. The contents of the drums will then be dumped into the mixer and blended for 10 minutes.

Step 5 - Add feldspar portion to sand-ore mix in truck and blend for an additional 10 minutes.

NOTE: All drum weights will be recorded on weigh out sheet. Keep all drums in their respective lots.

LOT CONTAINS:

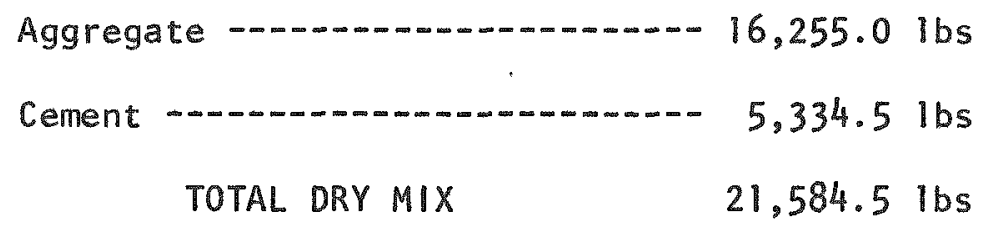

Multiply above figures by 10 to obtain pad figures. 
Additional Materials 2nd Revision (10/1/76)

\begin{tabular}{|c|c|c|c|c|c|c|}
\hline & $\begin{array}{l}\text { Sand } \\
\text { I bs }\end{array}$ & $\begin{array}{l}\text { Feldspar } \\
\text { lbs }\end{array}$ & $\begin{array}{l}\text { Uran ium } \\
\text { lbs } \\
\end{array}$ & $\begin{array}{l}\text { Thor i um } \\
\text { Ibs } \\
\end{array}$ & $\begin{array}{l}\text { Cement } \\
\text { Ibs }\end{array}$ & Total \\
\hline Pad 3 & $7,265.3$ & 959.2 & .35 & 11.55 & $2,667.0$ & $10,903.4$ \\
\hline $\operatorname{Pad} 4$ & $7,271.5$ & 946.4 & 14.25 & 0.95 & $2,667.0$ & $10,900.1$ \\
\hline Pad 5 & $4,541.2$ & $3,572.9$ & 9.4 & 4.1 & $2,667.0$ & $10,794.6$ \\
\hline TOTALS & $19,078.0$ & $5,478.5$ & 24.0 & 16.6 & $8,001.0$ & $32,598.1$ \\
\hline
\end{tabular}

Note: The above materials were added to Pads 3, 4, and 5 to assure enough cement for pads and to pour portable test cylinders. The same mixing procedures were used on the materials as outlined under the "Pad Weights and Blending Procedures" sheets. 
APPENDIX C

\section{PHOTOGRAPHIC REVIEW OF CONSTRUCTION ACTIVITIES}

Figures 1 through 17 


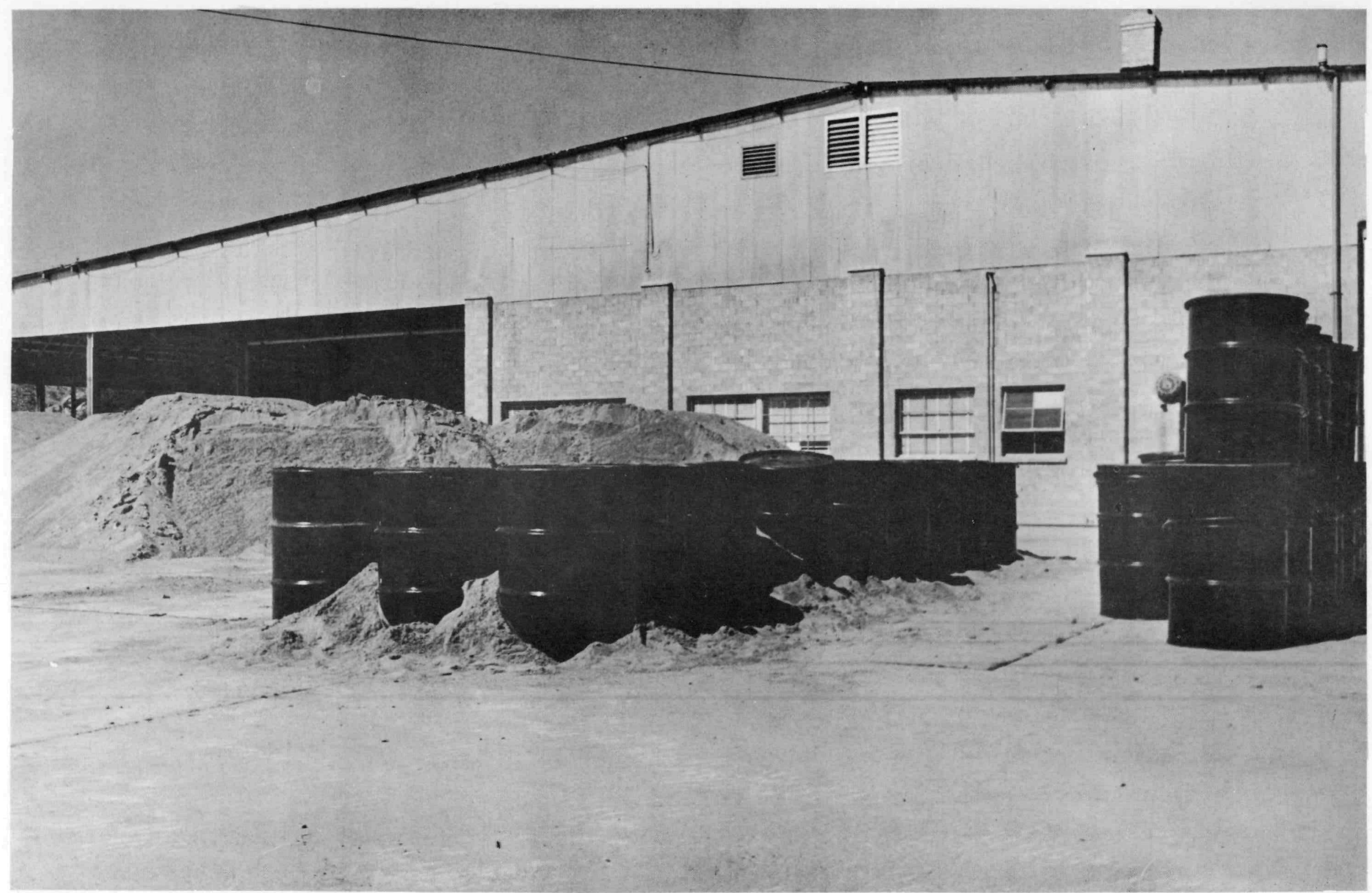

1. Masonry sand provided the matrix into which potassium $(K)$, uranium $(U)$, and thorium (Th) ores were blended to obtain the desired radioelement concentrations for the concrete pads. The sand was weighed and stored in 55 gallion drums. 


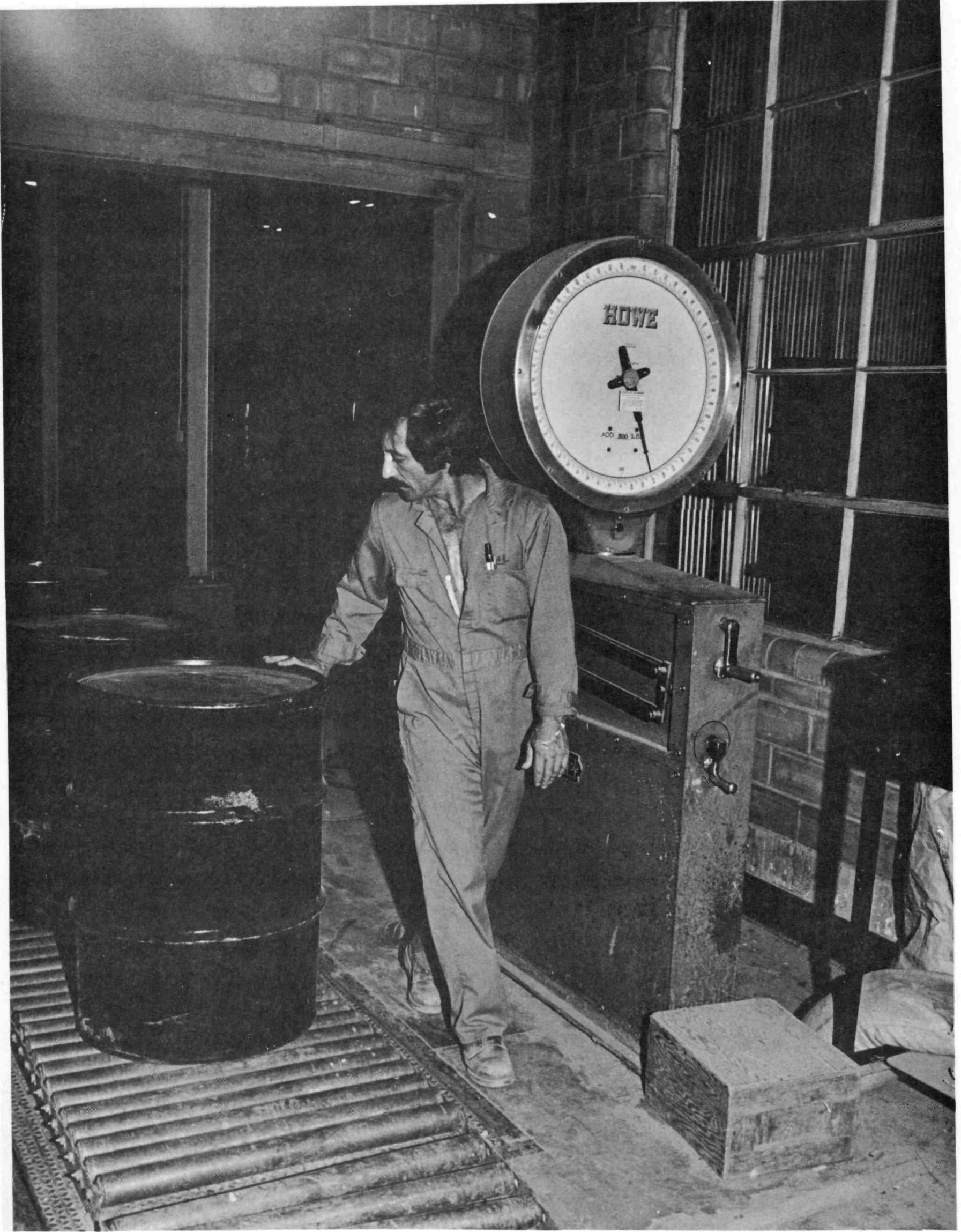

2. The sand, cement, and radioactive ores were chemically and radiometrically analyzed to determine the concentration of all elements (including $\mathrm{K}, \mathrm{U}, \mathrm{Th}$ ) and weighed so that a measured amount of each constituent could be blended together. 


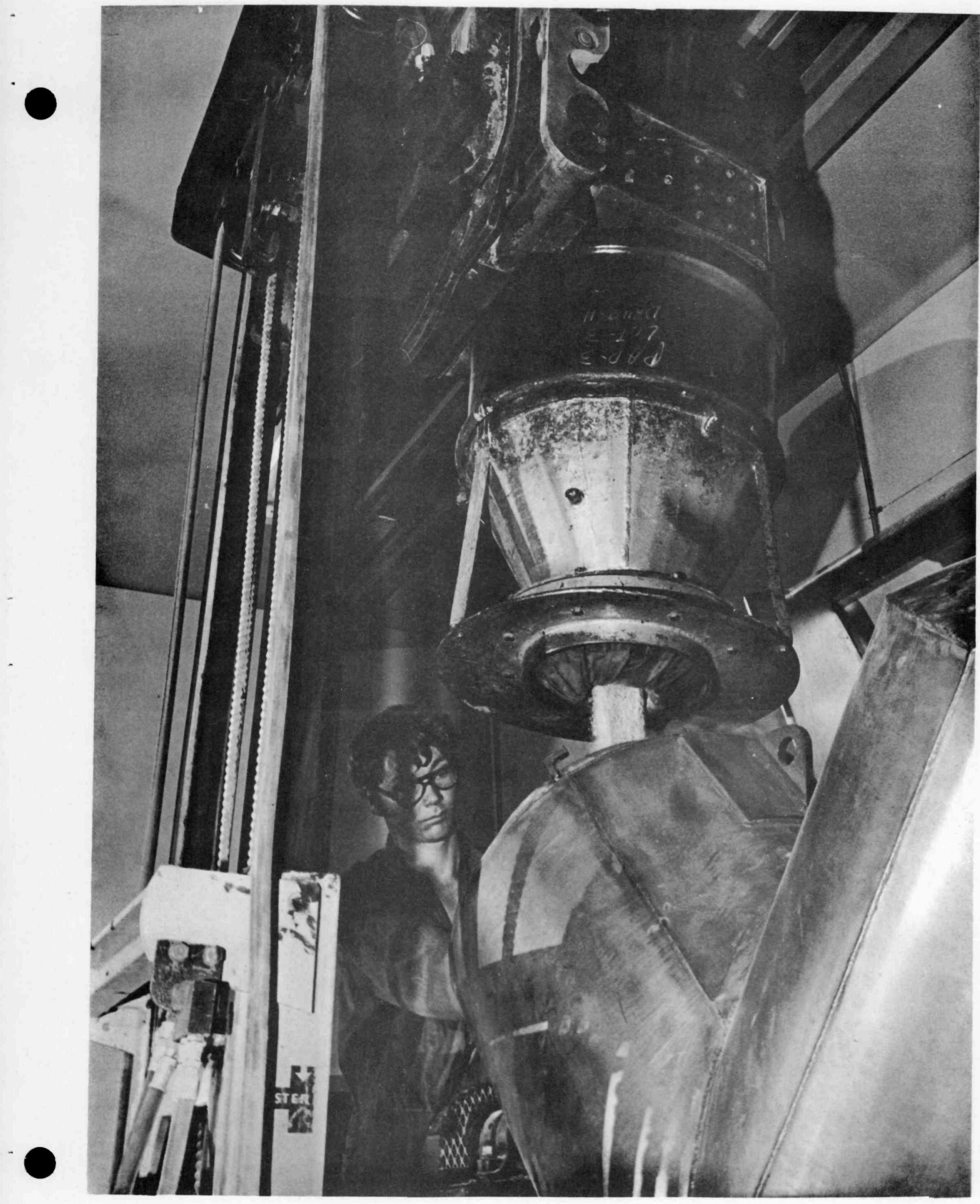

3. A drum containing a measured quantity of feldspar is poured into a $10 \mathrm{cu}$ ft laboratory blender. 


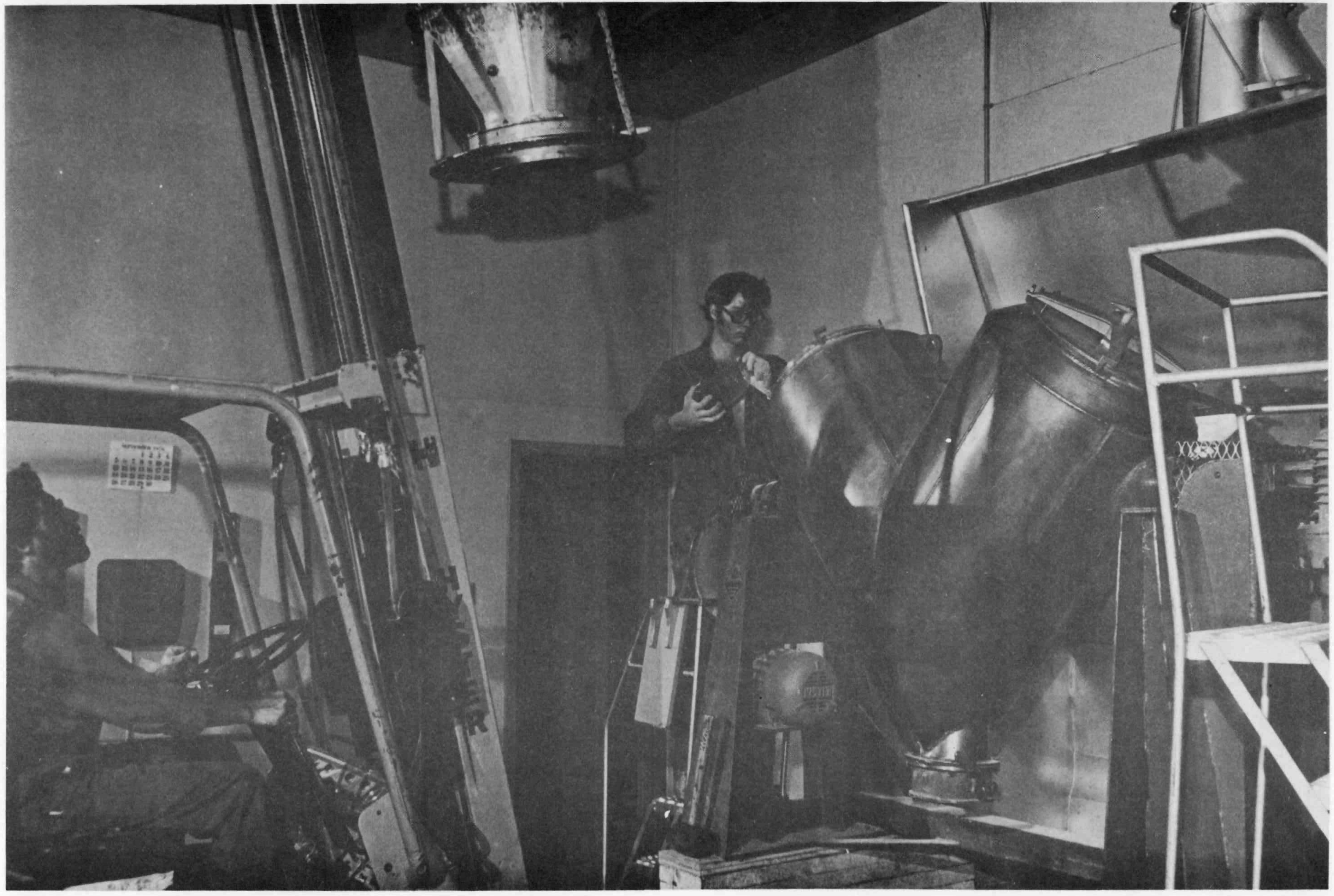

4. A blended mixture of uranium and thorium ores is poured from a bottle into a blender containing a measured quantity of feldspar. 


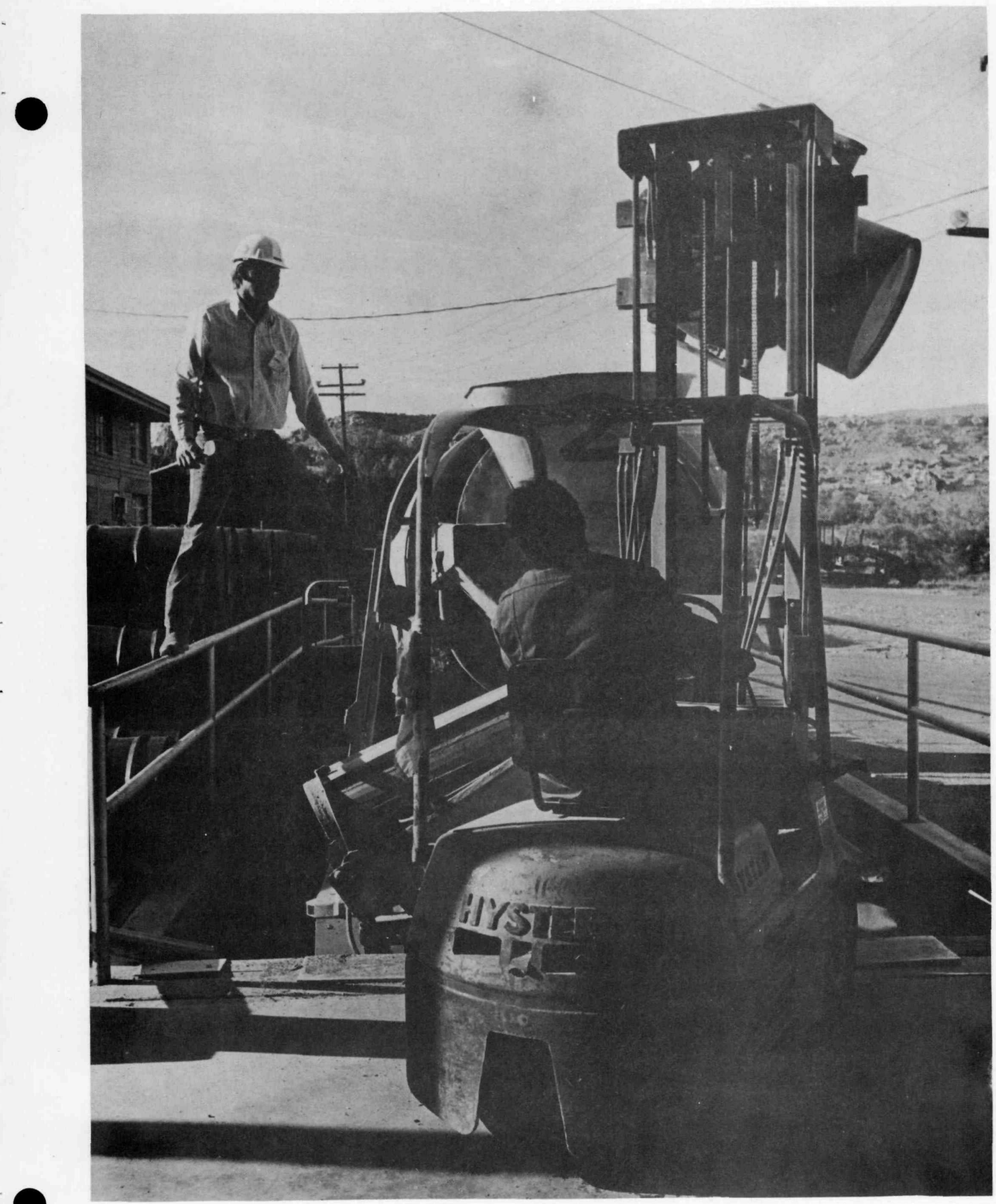

5. Blending of the feldspar-uranium-thorium mixture with the masonry sand required the use of a concrete mixer because the volume of the aggregate exceeded the capacity of the laboratory blenders. A hyster lifts the drum and pours the aggregate into the mixer. 


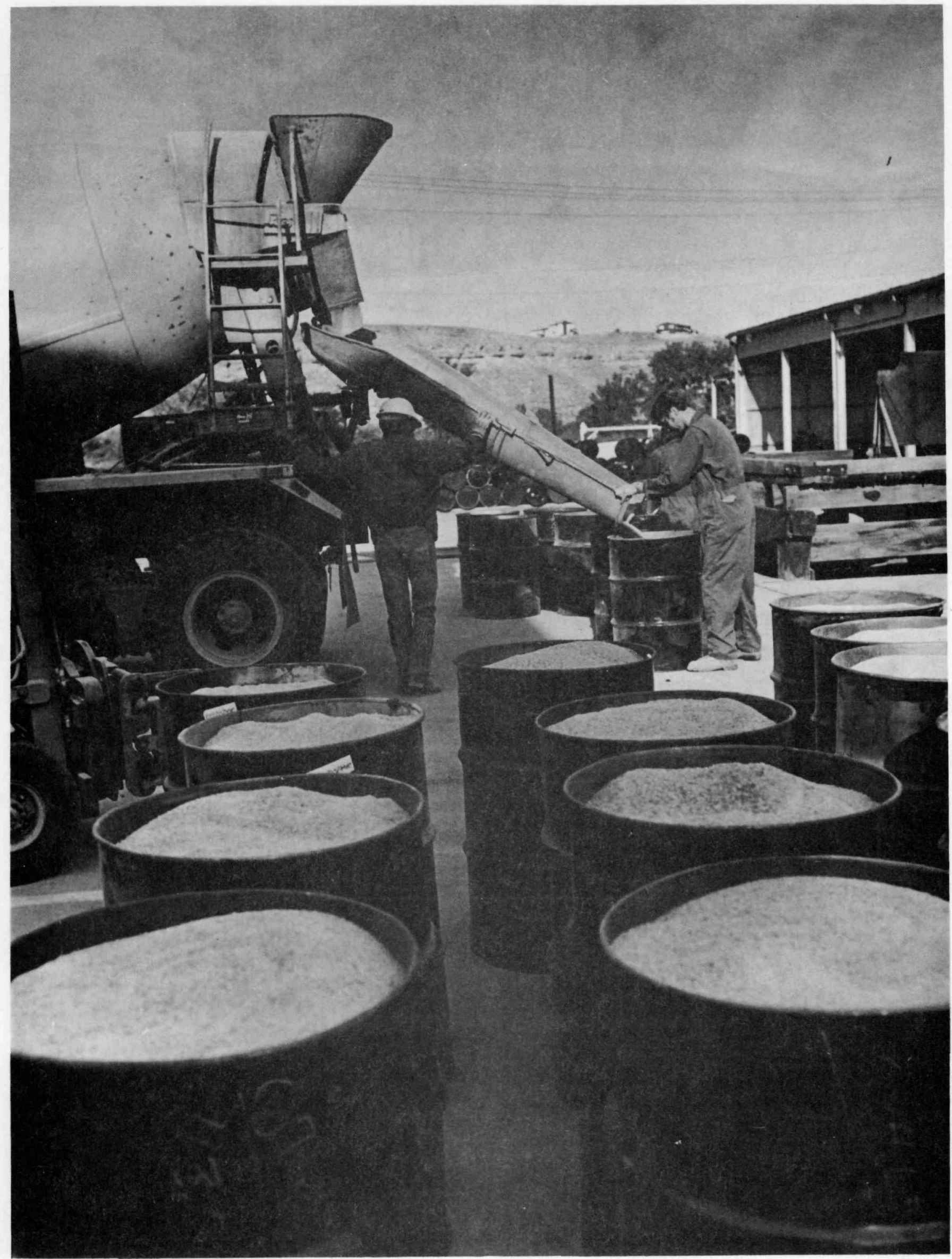

6. The concrete aggregate (sand-feldspar-uranium-thorium) is transferred from the blending mixer into drums for storage prior to being transported to the pad site where the cement and water were added. 


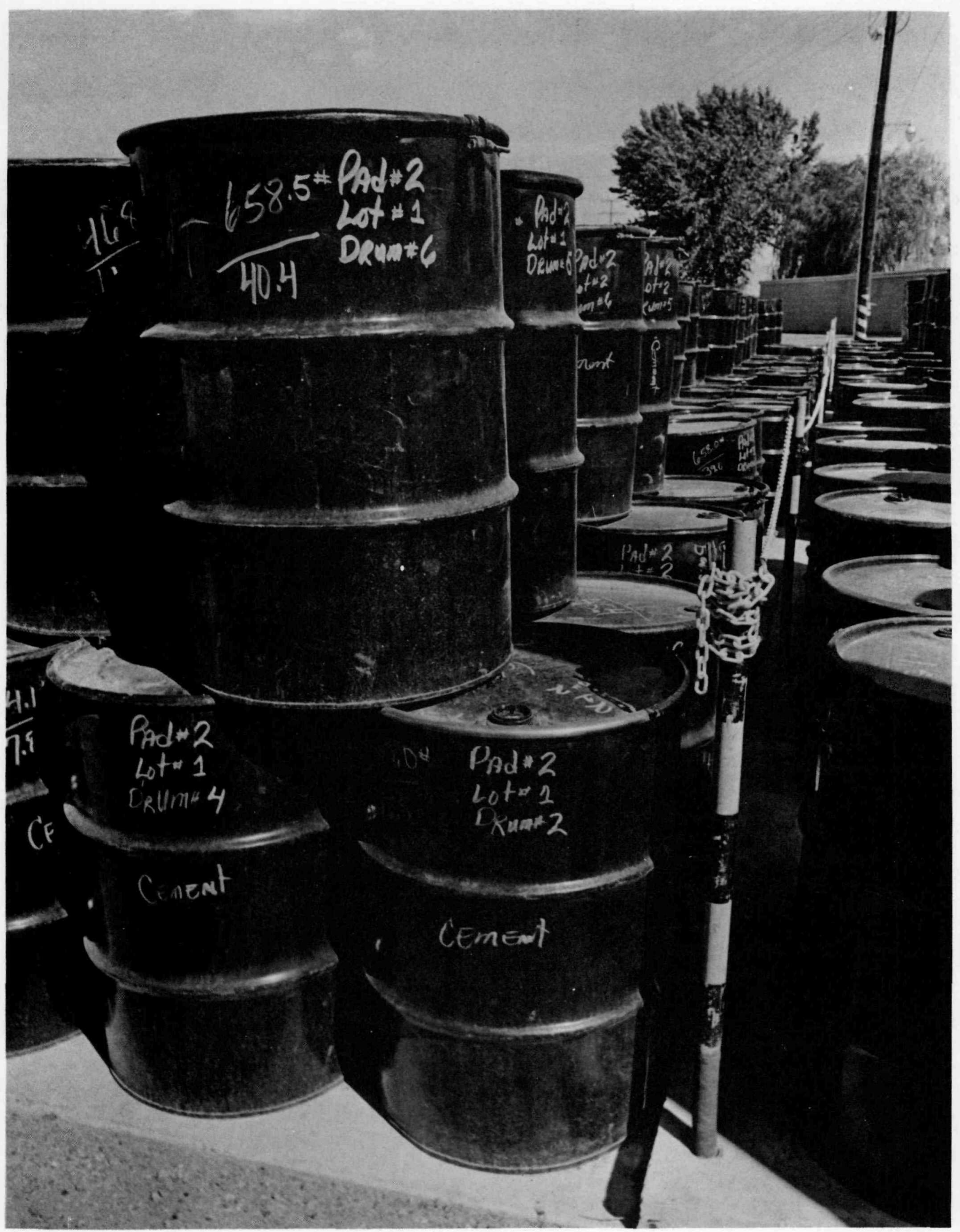

7. Drums containing the dry aggregate for each pad are labeled according to pad, lot, and drum number. Each pad contains about 67 cubic yards of concrete, and the total mixture for each pad was divided into 10 lots of about 7 cubic yards per lot, a volume that could be contained and transported in a mobile concrete mixer. 


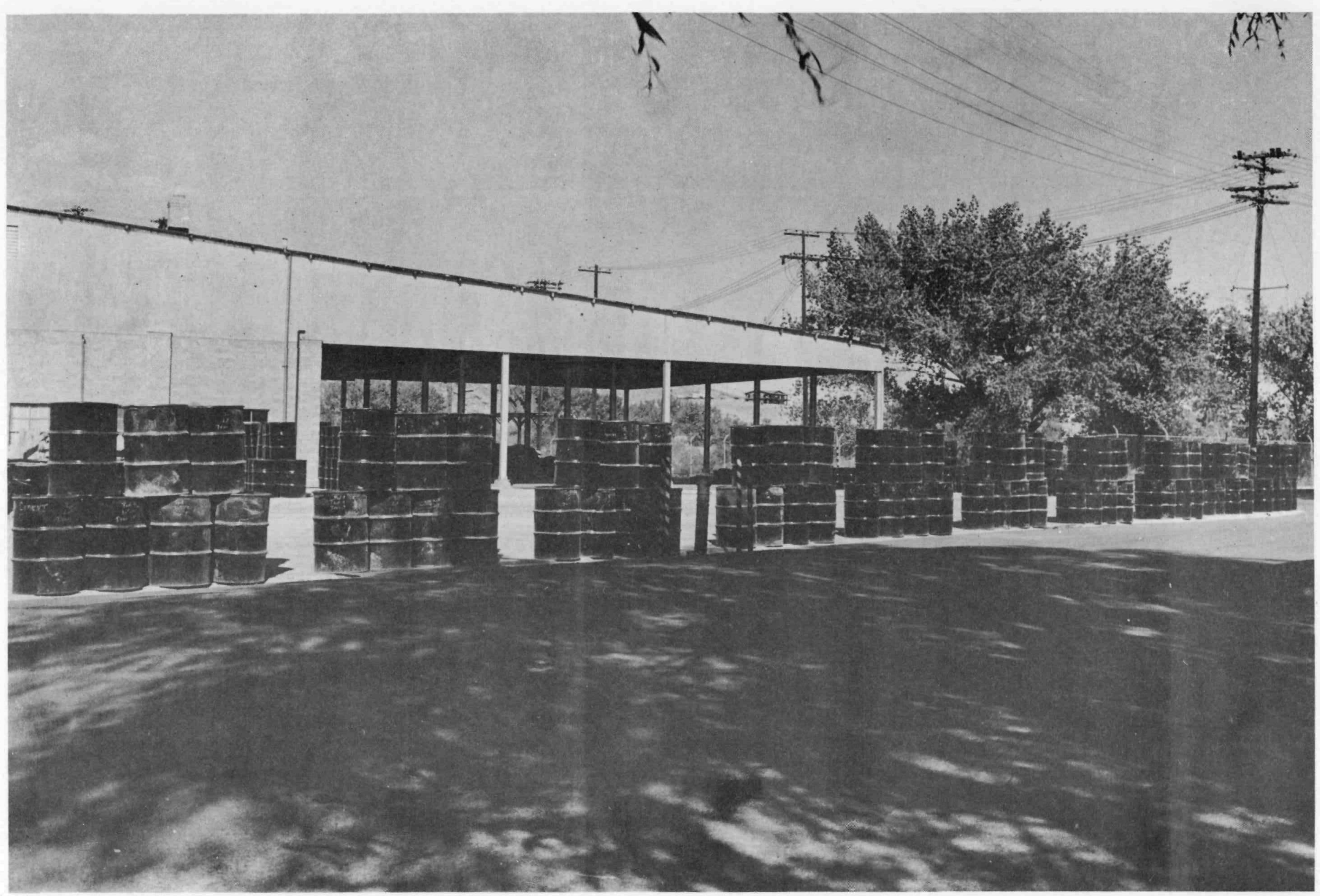

8. The aggregate mixture for each lot was stored in areas set aside for each of the five pads. 


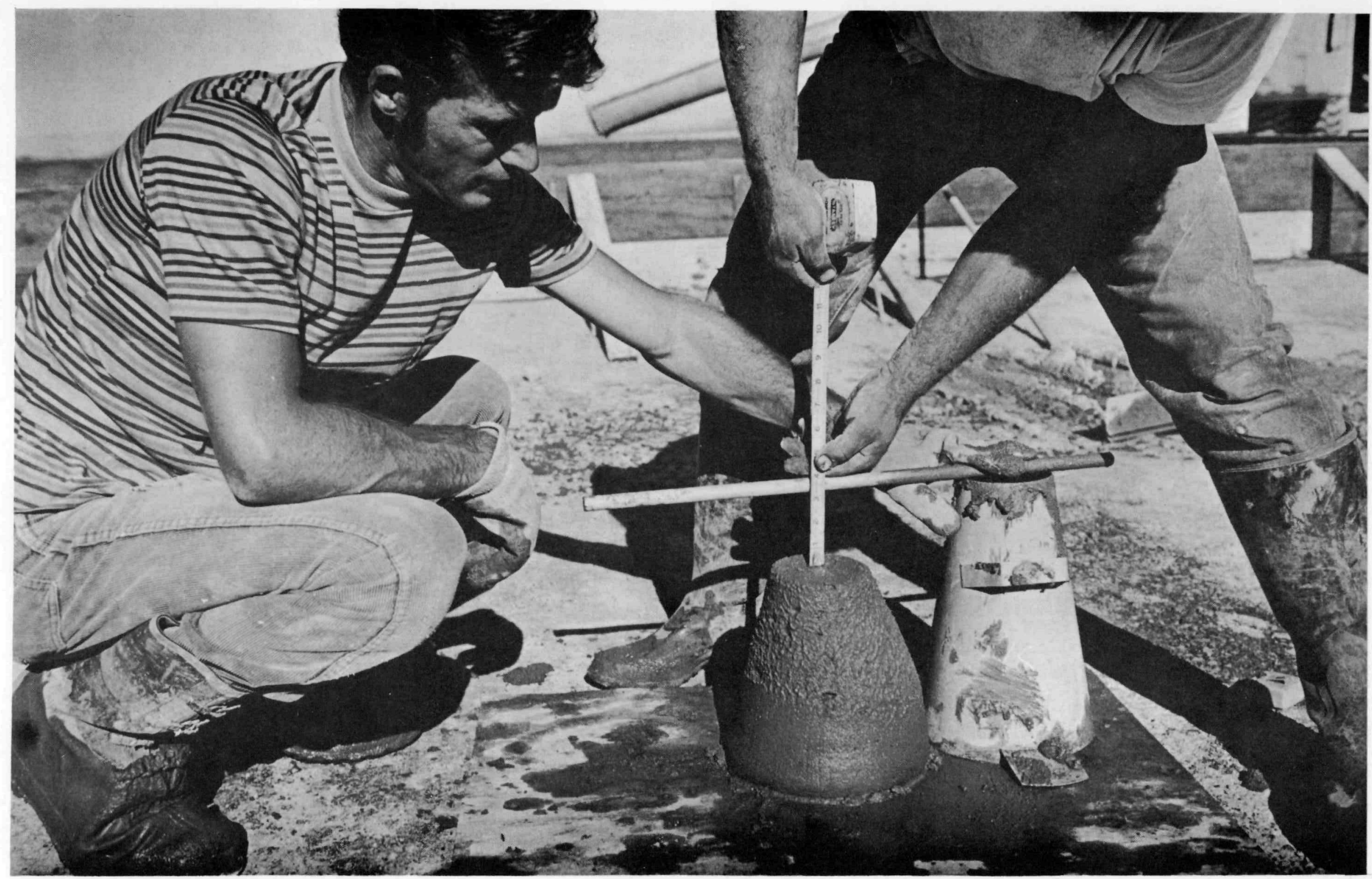

9. After measured quantities of water and cement were added to the aggregate and blended in the mixer truck for 10 minutes, a slump test as shown above determined the consistency of the mixture before it was poured into the forms. Controlling the consistency by the amount of water added to the aggregate aided in obtaining a uniform concrete density. 


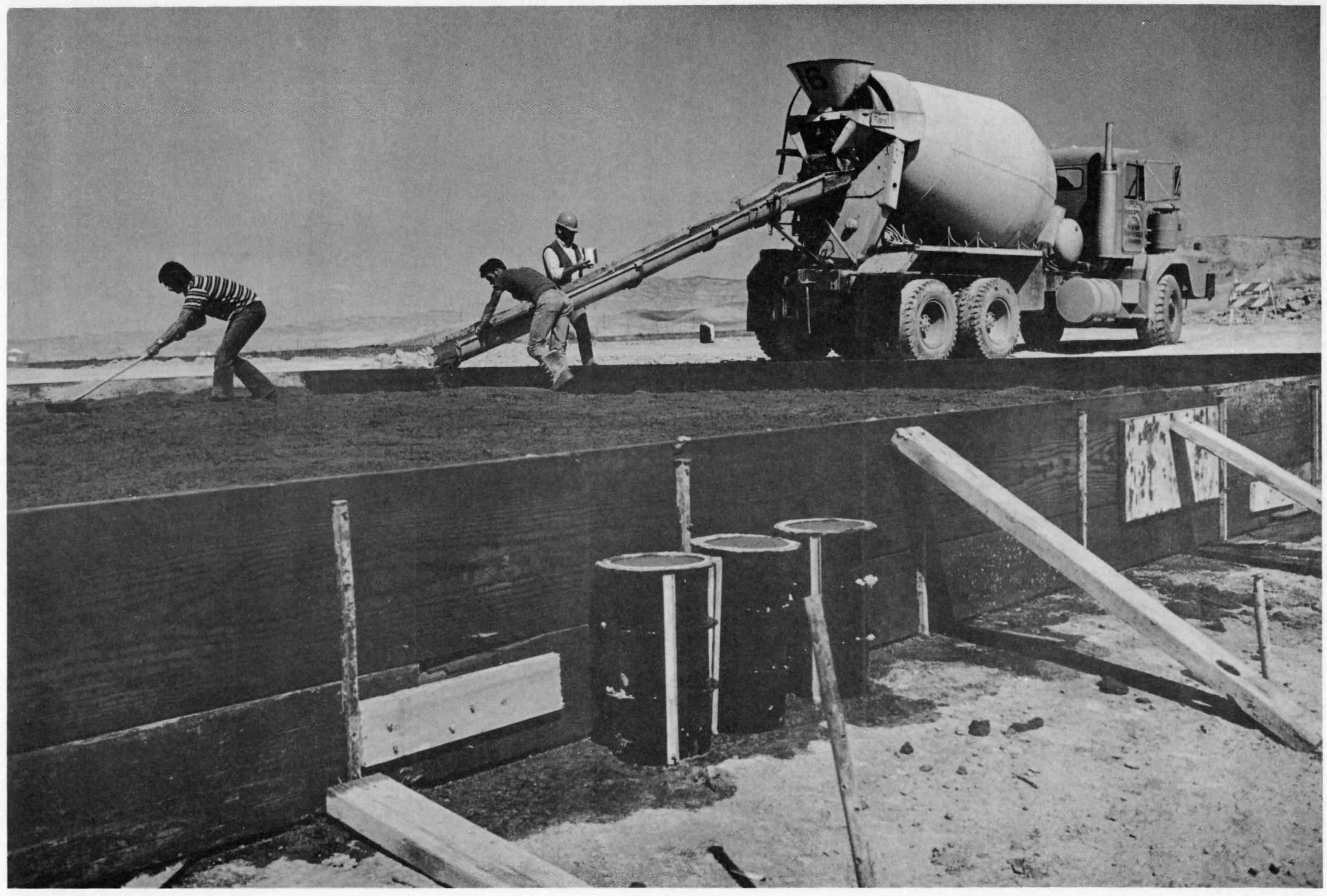

10. A mobile mixer containing one lot $(\approx 7 \mathrm{cu}$ yds $)$ of pre-mixed radioactive concrete is poured into a form. The level of the concrete mixture was maintained as the form was filled. 


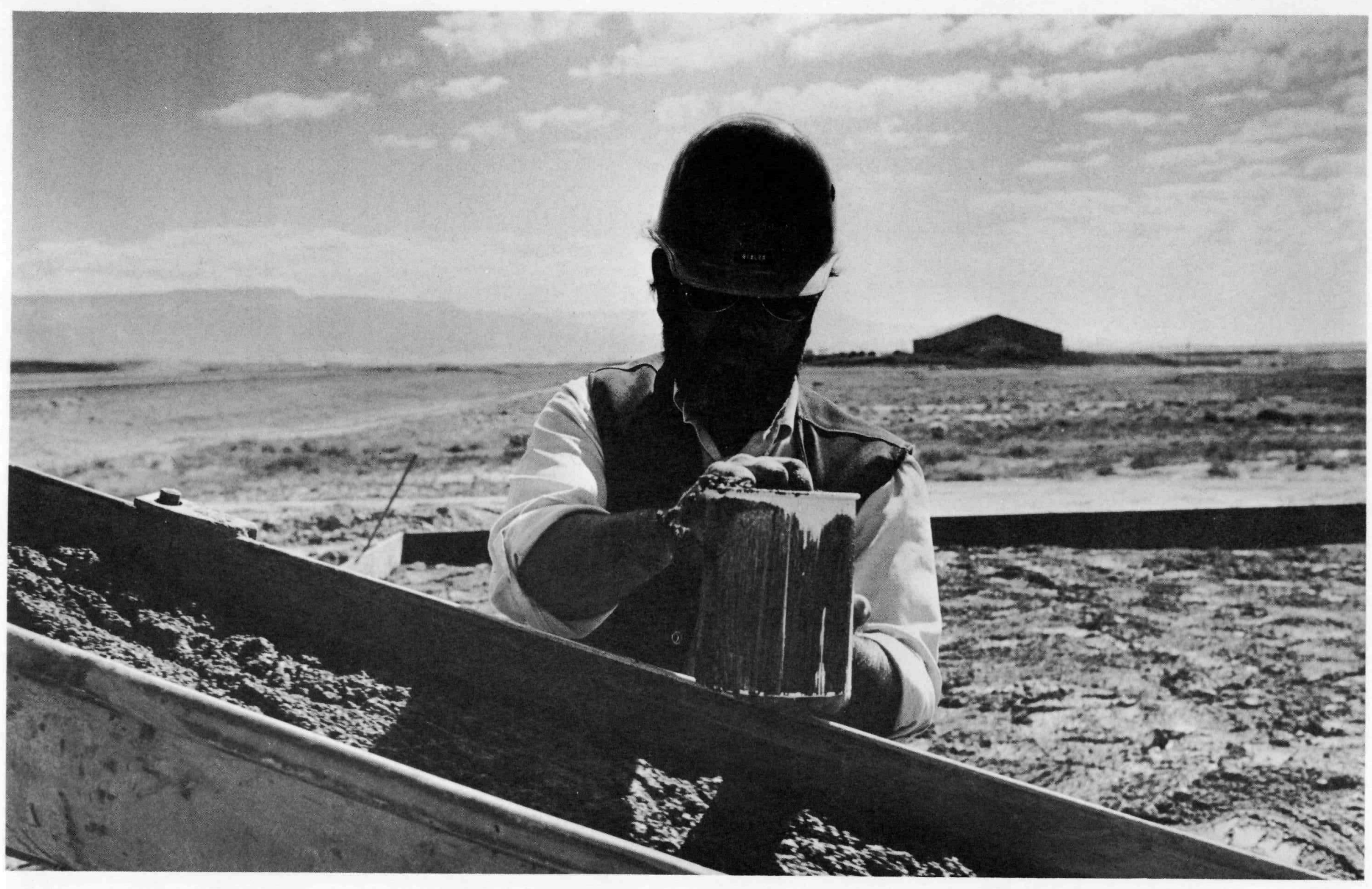

11. A one-half gallon sample of concrete is caught in an ice cream carton as it pours from the concrete mixer into the forms. Seven samples (app. one per cubic yard) were caught from each lot making a total of 70 one-half gallon samples from each pad. These samples were used for the chemical and radiometric assays to determine the radioelement concentrations of the pads. 


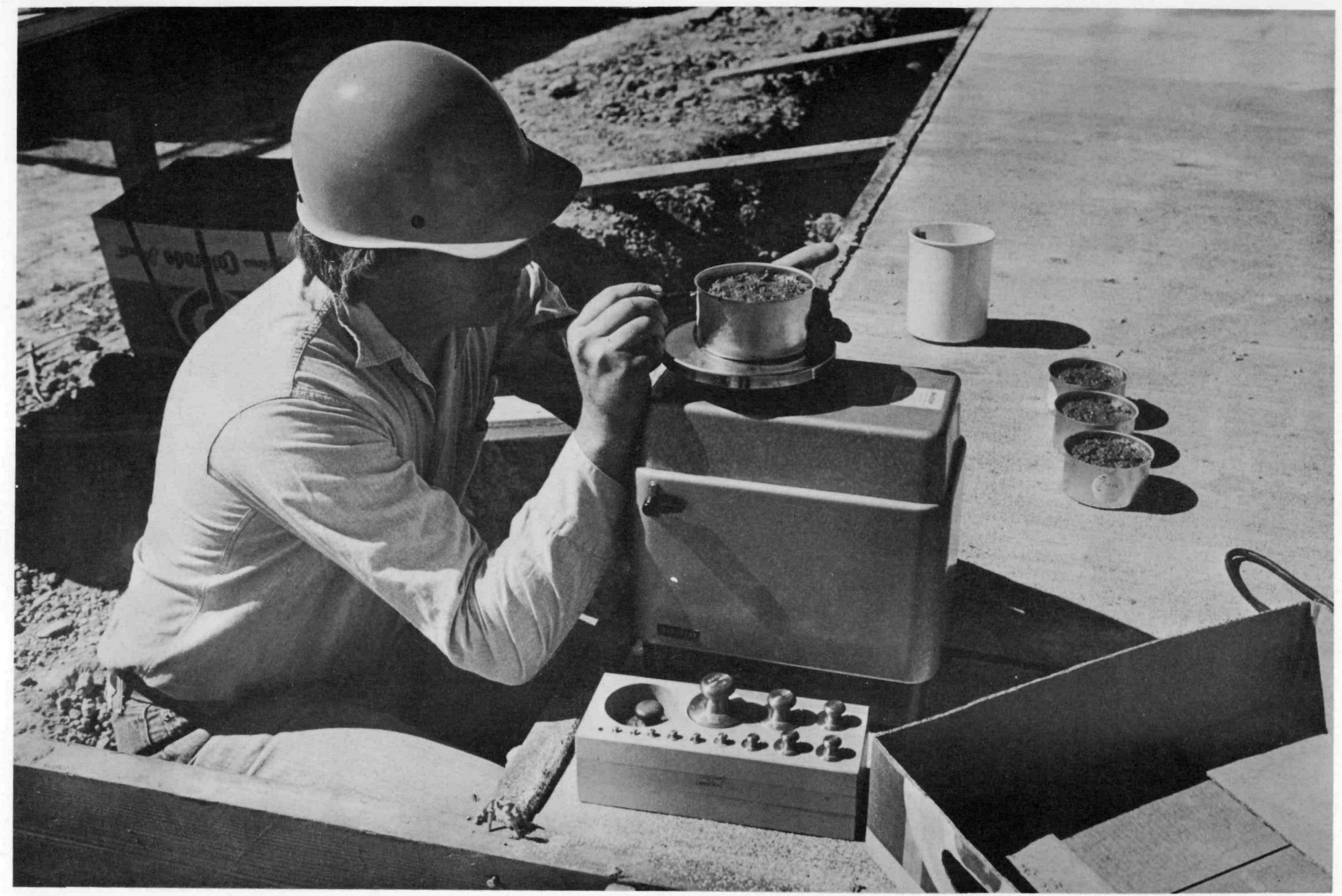

12. Concrete samples (70 per pad) were caught and weighed in $16 \mathrm{cc}$ tin alloy containers so that as-poured assays by gamma-ray spectroscopy could be determined. 


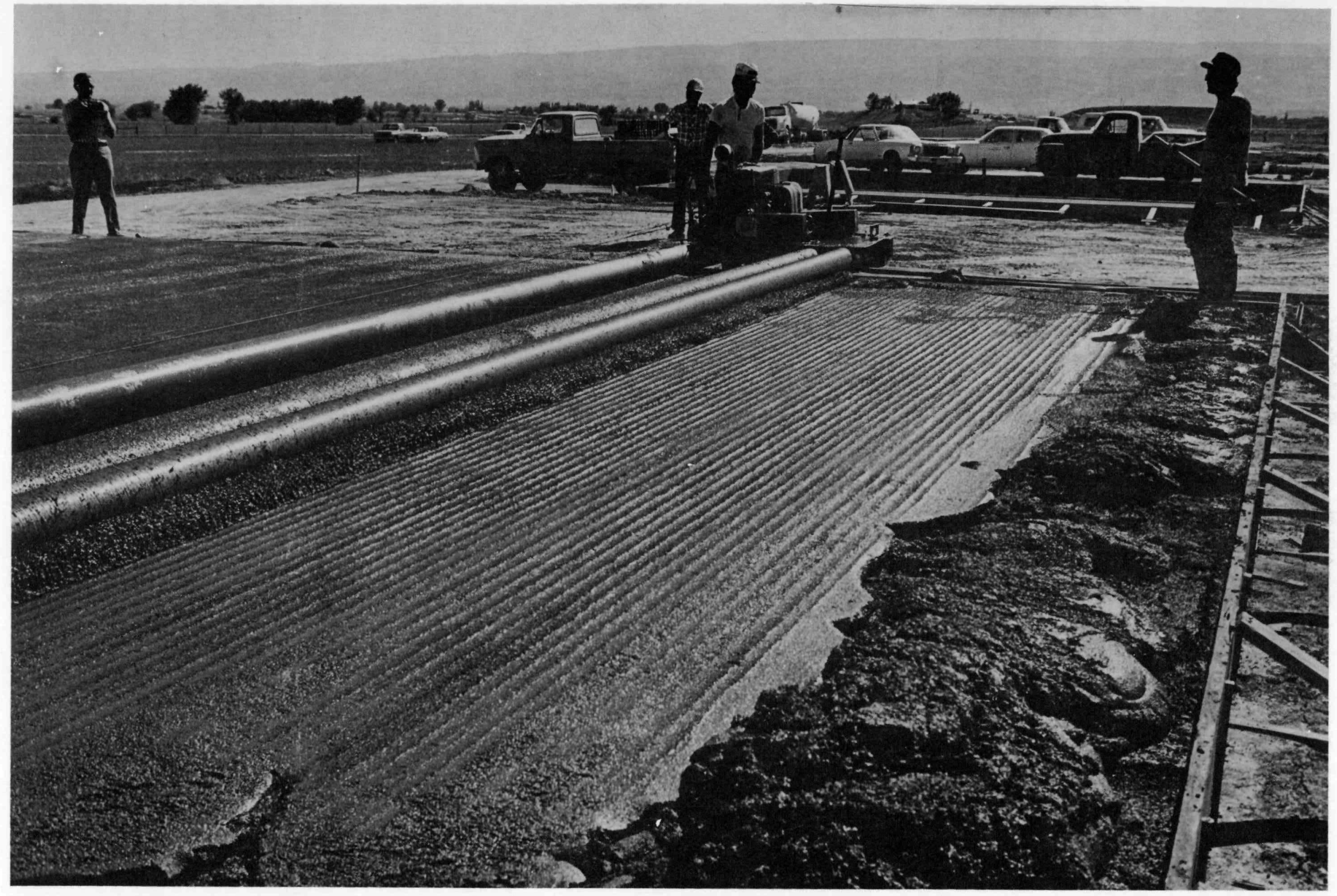

13. The surface of the pad was leveled with a mechanical screeder and then a brushed finish was applied by hand. 


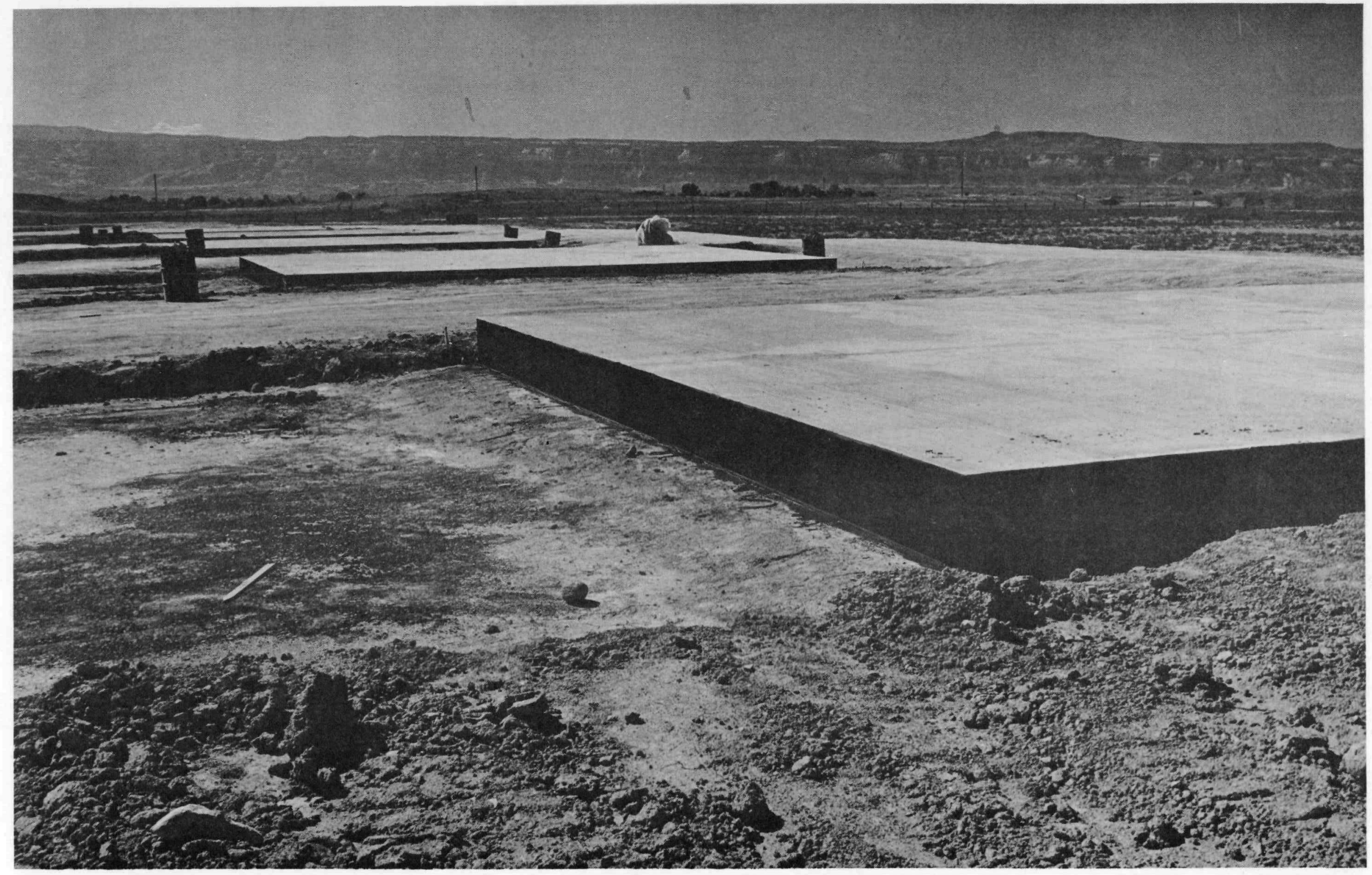

14. The concrete pad was poured on top of 6 inches of asphalt to provide a stable base and to prevent water encroachment under the pad. The edges of the concrete block were coated with an asphalt sealant prior to construction of the interconnecting asphalt taxiway and turnaround. 


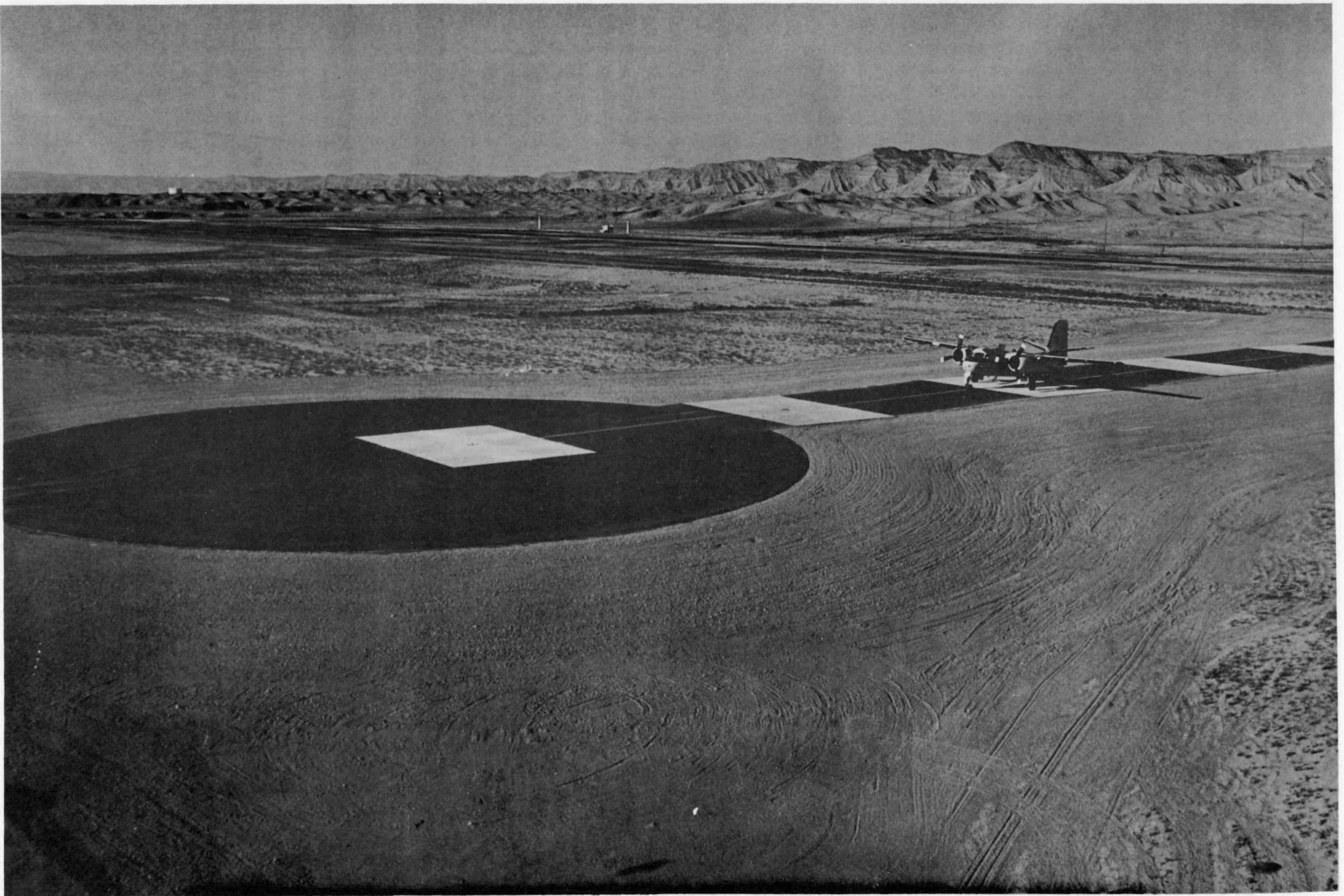

16. View looking north at plane calibrating on Pad 3. An asphalt turnaround is around Pad 5. 


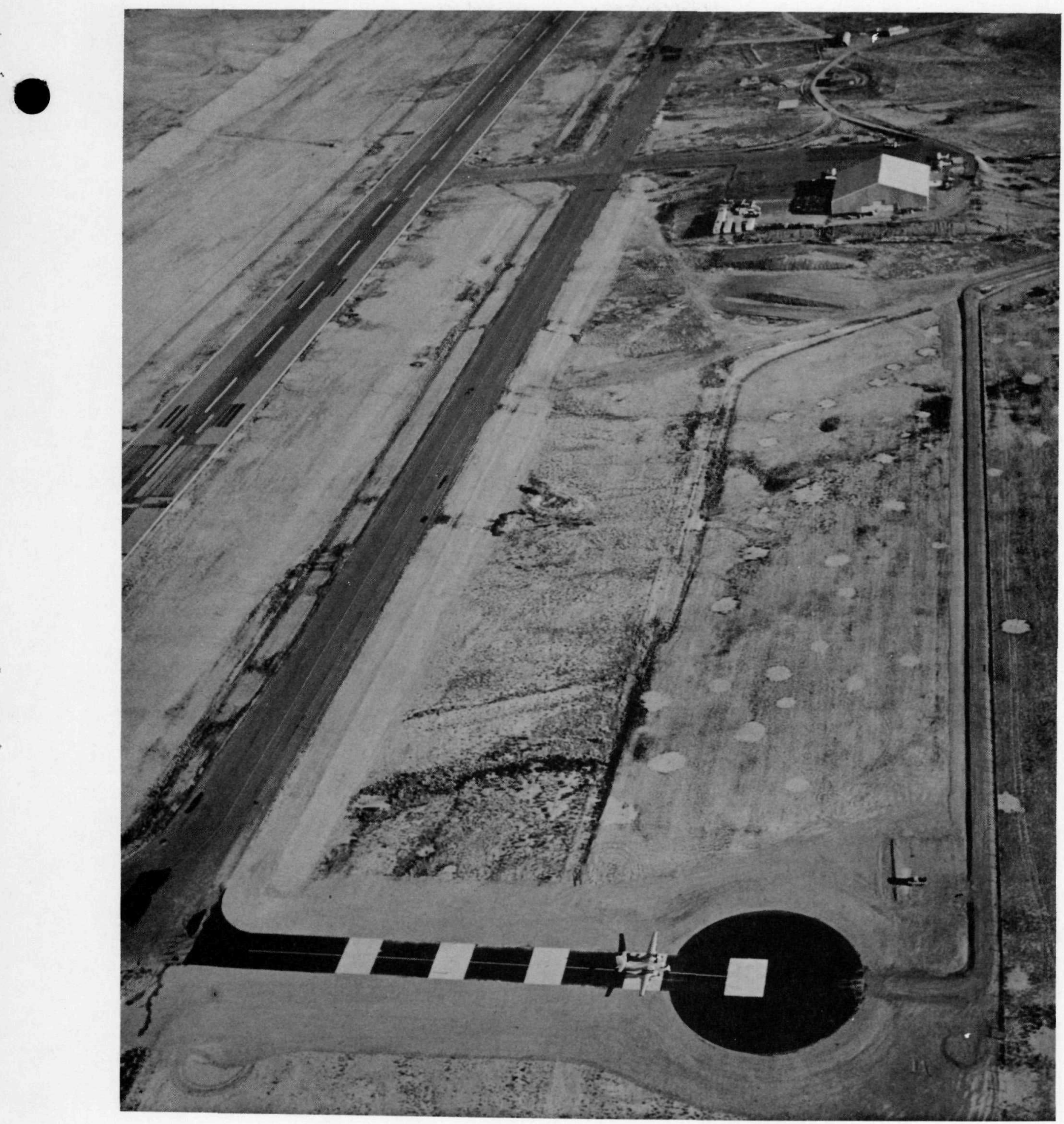

17. Aerial view of DOE calibration facility for gamma-ray spectrometers at Walker Field Airport, Grand Junction, Colorado. 